\title{
The cranial muscles of loricarioid catfishes, their homologies and value as taxonomic characters (Teleostei: Siluroidei)
}

\author{
Gordon J. Howes
}

Department of Zoology, British Museum (Natural History), Cromwell Road, London SW7 5BD

\section{Contents}

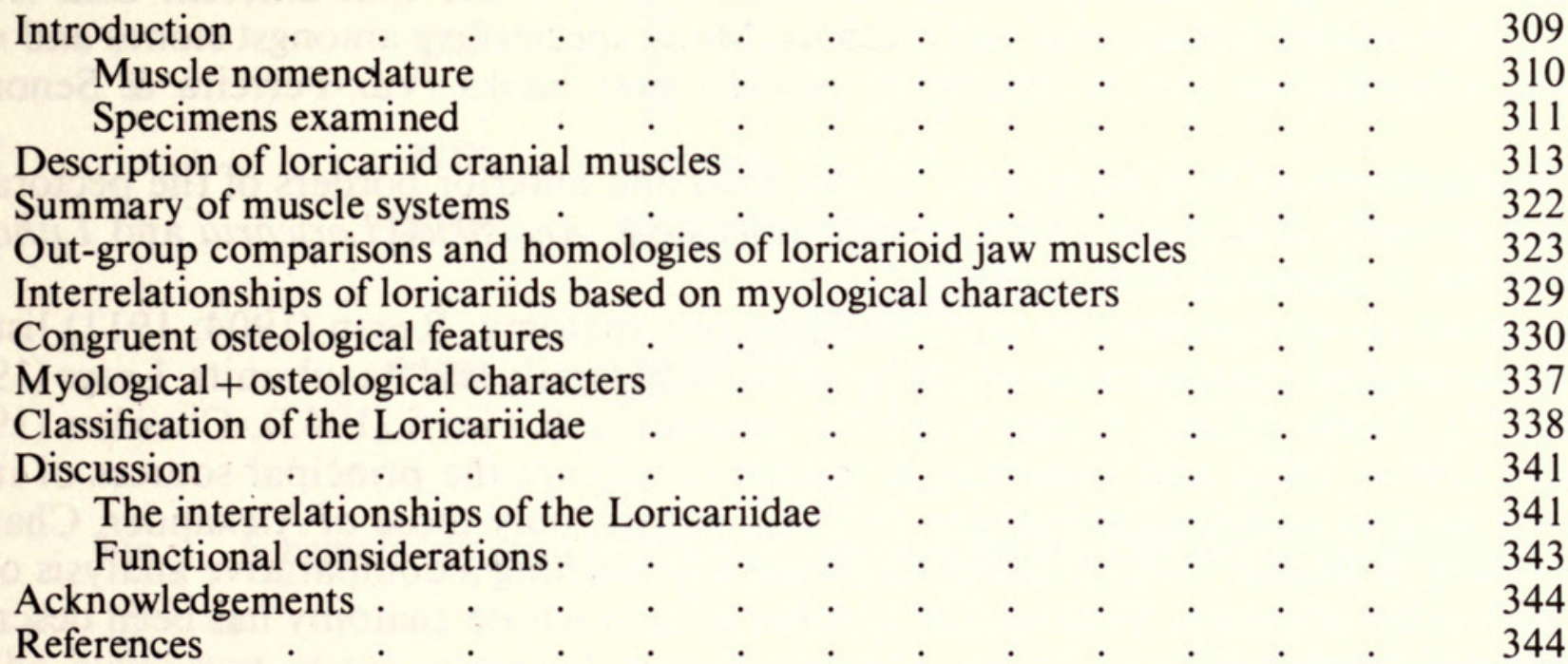

\section{Introduction}

The Loricariidae are a family of Neotropical siluroids (catfishes) with two outstanding external features: an 'armoured' body and a sucker-like ventrally situated mouth. The bodies of the catfishes are virtually encased in a series of bony plates or scutes reflecting the muscle segmentation (see Alexander, 1965: 136) and the heads are covered with a mosaic of bony plates. The bony plates generally run in an overlapping series of 5 longitudinal rows, but in those forms with an attenuated and compressed caudal peduncle, the series may be reduced posteriorly to two. All the plates, most of the head covering, the fin spines and rays bear spines. In some taxa, particularly in males, the spines may form dense clumps on the tops and lateral parts of the head. The operculum and interoperculum also bear spines which on the latter, may be attenuated and hooked.

The spines, or denticles all appear to have a similar structure, namely dentine surrounding a pulp cavity and with an enamel cap (see Bhatti, 1938). Thus, to all intents and purposes they are to be regarded as teeth. Ørvig (1977) used the term 'teeth' for those dental elements confined to the jaws and 'odontodes' for similar elements occurring on the extra-oral dermal skeleton. In this paper, 'odontodes' will be used to refer to such spines, prickles and bristles on the scutes, head and fin rays.

The sucker-like mouth is in the form of reflected upper and lower, usually papillate, lips. They surround highly mobile jaws (see p. 343) which often bear long, usually bifid, hooked teeth. The jaws may be long and shallow with the teeth numerous, arranged in regular rows e.g. Chaetostoma, short and deep with the teeth few and clumped together e.g. Pseudacanthicus, or lamellate and edentulous, some Loricaria. 
Alexander (1965) has described the mouth and its functional morphology. He showed how the modified mouth, body scutes and fins are all features associated with the torrential and benthic environments of loricariids.

In terms of numbers of taxa, the Loricariidae is the largest siluroid family, containing $c a$ 70 genera and 600 nominal species (Isbrücker, 1980). Whether or not this number of taxa are a reflection of the taxonomic concepts of various authors is a matter for debate (see. p. 339) but even if many proved to be synonyms, it is likely that the family would retain its numerical supremacy.

Of the currently recognized genera (Isbrücker, 1980) approximately $50 \%$ occur in the Amazon basin, $30 \%$ in Guianas, $20 \%$ in both the Orinoco and trans-Andean regions, $25 \%$ in Parana, $15-16 \%$ in the Magdalena and Andes, and 10\% in south-eastern Brazil.

The biology of loricariids is poorly known. Most appear to feed on algae or perhaps organisms that live in algal mats. Angelescu \& Gneri (1943) found that different taxa fed on molluscs, chironomid larvae, mud and diatoms. Many species live amongst stones and roots and some Hypostomus live in tunnels in muddy river banks (Vaz-Ferreira \& Senorans, 1971).

The development of long odontodes on the head and anterior borders of the pectoral fin spines are sexually dimorphic characters in some taxa, Ancistrus, Loricaria and Lithoxus; their function is discussed later, p. 343.

There exists no comprehensive work on loricariid anatomy. Regan $(1904 ; 1911)$ listed a series of osteological characters by which he defined the family and its subunits. Leege (1922), Peyer (1922), Starks (1926), Gregory (1933), Angelescu \& Gneri (1943), Chardon (1968), Alexander $(1964 ; 1965)$ and Lundberg \& Baskin (1969) are the principal sources of information on various osteological features. Of these papers, only those of Alexander, Chardon and Lundberg \& Baskin have provided anything approaching a comparative analysis of the family with other siluroids. Even so, the number of taxa whose anatomy has been described has been exceedingly small.

Only one paper, that of Alexander (1965), has described the musculature of loricariid fishes in any detail. The earlier paper by Leege (1922) has negligible myological information. Alexander limited his description of jaw musculature to Hypostomus, = Plecostomus in Alexander, and the opercular musculature (part) of Ancistrus. Alexander's work was aimed primarily at a functional description, and detailed myological description was lacking.

The principal aim of this paper is to go some way towards filling the lacunae of knowledge about loricariid myology. By making out-group comparisons with other siluroids and otophysans the muscular system of loricariids are viewed in terms of character states and used to construct a cladogram. This scheme is compared with others utilizing selected osteological characters and the resultant information is used to produce a cladogram of nested synapomorphies for those taxa studied. No detailed treatment of loricariid interrelationships is presented. As yet no cladistic framework is available for any group of siluroid fishes and so any comments on interrelationships must be regarded as highly speculative.

Some attention is given to the possible function of the muscular systems described.

\section{Muscle nomenclature}

The adductor mandibulae muscle complex of teleostean fishes is usually recognised as being divisible into several elements each identified by a lettering sequence $A_{1}-A_{w}$, following Vetter (1878). As various subdivisions of these elements have been recognised, they have been identified by addition of a subscript letter or numeral. This system of nomenclature has, in some instances, resulted in complex notations (see for example Matthes', 1963, system for cyprinids). More important, however, is whether those elements similarly labelled in different taxa represent homologues-a question discussed later (p. 323).

In most siluroids, the morphology of the adductor mandibulae is complex, and this is particularly so in loricariids. In order to clarify the following descriptions the muscles are shown schematically in Fig. 1. 


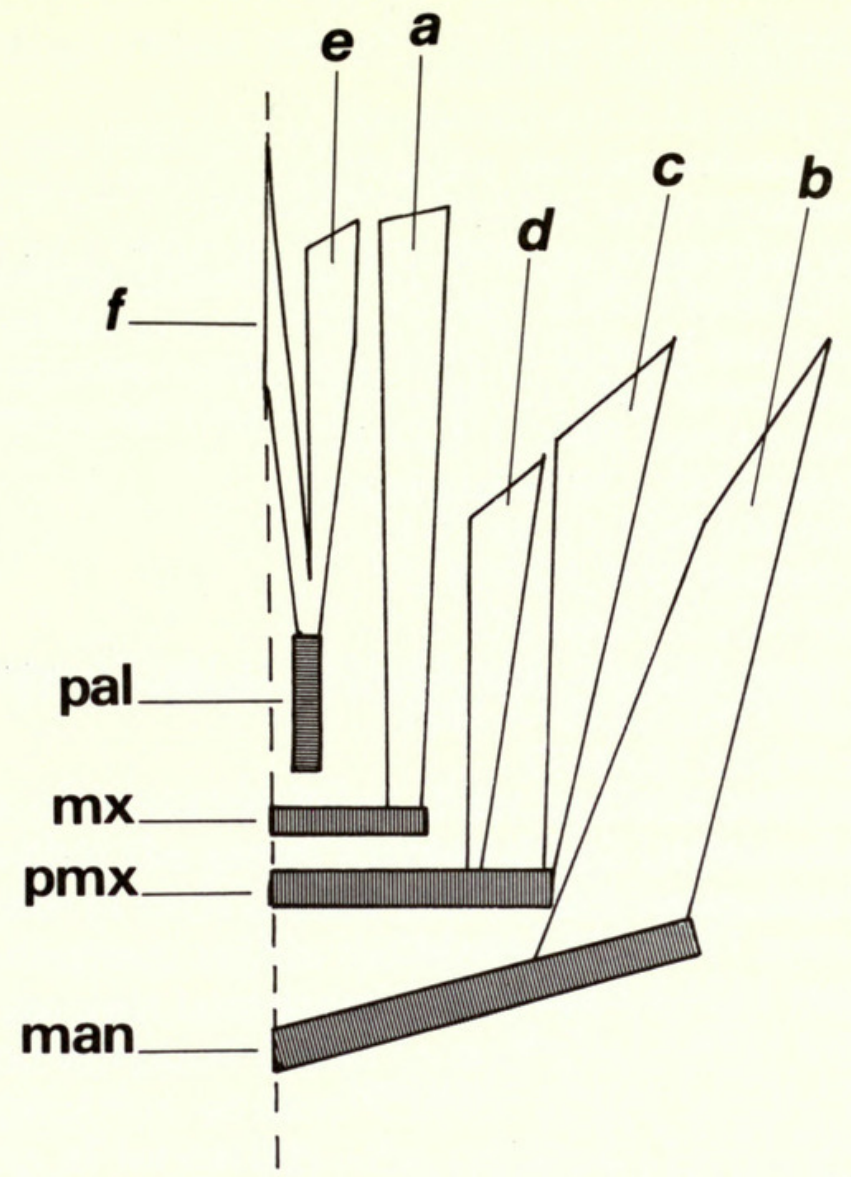

Fig. 1 Schematic diagram of loricariid jaw-palatine muscles and their insertions.

The outer part of the adductor muscle complex, which in more advanced teleosts runs to the maxillary bone of the upper jaw, designated as $\mathrm{A}_{1}$, inserts, in siluroids, on to the lower jaw. The muscle having its insertion on to the maxilla is recognised as the retractor tentaculi. The phylogenetic origin of this muscle is possibly from a medial part of the adductor mandibulae; see Howes (1983), and below, p. 327 for discussion of homology. The number of medial divisions of the adductor complex in loricariids exceeds that of other siluroids, and possibly that of other otophysans. This multiplication of elements leads to difficulties in using the generally applied system of notation since their respective homologies are uncertain (see p. 327). Thus, for descriptive purposes all jaw muscles are designated a-f.

Muscle $\mathbf{a}$ is that inserting on the maxilla; muscles $\mathbf{b}-\mathbf{d}$ are various divisions of the adductor mandibulae; muscles e-f attach to the palatine bone and are derivatives of the adductor arcus palatini.

Other suspensorial, opercular and hyoid muscles are named according to the nomenclature of Winterbottom (1974) and their homologies with those muscles so named in other teleosts are accepted.

\section{Specimens examined}

The specimens listed are those dissected for this study. In addition, dissections, skeletons, alizarins and radiographs of specimens representing nearly all siluroid families have been examined.

Loricariidae: Ancistrus occidentalis 1981.1.5:722-748; 749-797

Ancistrus stigmaticus 1901.5.8:10 (skeleton)

Ancistrus spp Uncatalogued (skeleton)

Chaetostoma anomalum 1903.6.30:102 (skeleton)

Chaetostoma breve 1898.11.4:38 (skeleton)

Chaetostoma dermorhynchus 1880.12.8:64-66

Chaetostoma microps 1981.1.5:821-867 
Cochliodon cochliodon 1981.1.5:777-787

Cochliodon sp. Uncatalogued (alizarins)

Farlowella knerii 1880.12.5:206 (skeleton)

Farlowella spp Uncatalogued (inc. alizarins)

Hemiancistrus megacephalus 1972.10.17:872-875

Hemiodonichthys acipenserinus 1879.12.1:75-79; 1977.3.10:186

Hemipsilichthys calmoni 1929.2.1:66-71

Hypoptopoma carinata 1926.10.27.367-73

Hypostomus plecostomus 1981.1.5:760-776

Hypostomus spinossisimus 1898.11.4:30-31

Hypostomus verraes 1895.3.29:38 (skeleton)

Ixinandria montebelloi 1981.11.30:13-15

Lipopterichthys carrioni 1935.5.20:18-27

Lithoxus lithoides 1972.7.17:66-115

Loricaria cataphracta 1926.3.2: 765-82; 1860.11.10:15 (skeleton)

Loricaria brunneus 1981.6.9:1074-1081

Loricaria jubata 1914.5.18:68-72

Loricaria labialis 1934.8.20:368-388

Loricaria lanceolata 1981.1.5:873-904

Loricaria microlepidogaster 1929.2.1:29-50

Loricaria platystoma 1974.5.22:544-545

Loricaria simillima 1934.8.20:326-46

Loricaria strigilata 1929.2.1:31-40

Loricaria teffeana 1895.5.17:103 (skeleton)

Loricaria variegata 1914.5.18:73

Loricaria venezeuelae 1947.7.1:228-232

Loricaria spp Uncatalogued (alizarins)

Metaloricaria nysseni 1982.4.7:7

Rhadniloricaria macromystax 1869.5.21:8

Neoplecostomus granulosus 1896.7.4:3-5; 6 (skeleton)

Otocinclus nigricauda 1934.8.20:220-240 (alizarin)

Panaque nigrolineatus 1974.8.14:13-15

Peckoltia pulcher 1980.7.1:87; uncatalogued

Pogonopoma wertheimeri 1904.1.28:6

Pogonopomoides parahybae 1904.1.28:7

Pseudacanthicus serratus 1870.3.10:4 (skeleton)

Pseudancistrus barbatus 1972.7.17:49-50

Pseudohemiodon sp. Uncatalogued

Pseudohemiodon laticeps 1895.5.17:113-4

Pterygoplichthys anisitsi 1934.8.20:255-64

Pterygoplichthys multiradiatus 1897.12.1:280 (skeleton)

Stoniella leopardus 1973.7.17:188-198

Sturisoma panamense Uncatalogued

Sturisoma lyra 1897.12.1:72 (skeleton)

Astroblepidae: Astroblepus festae 1894.11.4:18 (skeleton) Astroblepus heterodon 1910.7.11:138 (skeleton)

Astroblepus grixalvii 1898.11.4:12-17

Astroblepus cf. praeliorum 1969.1.27:35-46

Callichthyidae: Callichthys callichthys 1981.6.9:995-1005; uncatalogued Hoplosternum littorale 1934.9.12:413-420

Diplomystidae: Diplomystes papillosus 1889.11.14:33; 1896.10.2:22 (skeleton)

Doradidae: Amblydoras hancocki 1971.4.14:15-30

Mochokidae: Euchilichthys royauxi 1909.4.29:98-102

Nematogenyidae: Nematogenys inermis 1883.11.27:45-48; 49 (skeleton) 
Scoloplacidae: Scoloplax dicra UMMZ 198967, Paratypes (inc. alizarins)

Sisoridae: Glyptosternum cous 1968.12.13:471-76

Glyptothorax major 1978.3.20:286-289

Trichomycteridae: Branchioica magdalenae 1947.7.1:203-8 (alizarins)

Eremophilus mutisii 1978.2.22:16

Trichomycterus cordovense 1911.11.25:1-10

Trichomycterus rivulatus 1944.6.16:142-5

\section{Jaw muscles}

Whilst the jaw muscles of loricariid fishes differ in their arrangement from those in other siluroids (see p. 323), within the group there is a high degree of uniformity. Differences are marked by the relative size of each muscle and by varying points of insertion. Both variables are diagnostic for sub-groupings within the family.

In order to present a succinct comparative analysis, the jaw musculature of one taxon will be described in detail and attention drawn to taxa which differ from that plan. The representative taxon is Pterygoplichthys anisitsi. Choice of this species is determined by its representing the largest group of loricariids-the subfamily Hypostominae (see p. 338), and by what may be termed its relatively generalised morphology. This latter impression does not imply that the taxon is primitive or plesiomorphic.

When the thick, plate-like epidermis is removed from the side of the head in Pterygoplichthys three large muscles are exposed. The medial, band-like muscle (a, Fig. 2A) originates from the lateral margin and ventral surface of the lateral ethmoid passes laterally to the palatine and inserts on the maxilla. The maxillary ramus of the trigeminal nerve runs along its lateral border and sends a branch into the muscle's ventral surface. The buccal ramus passes across the dorsal surfaces of the muscle and the palatine to enter the maxilla.

The outer muscle (b), originates below the eye and inserts on the lower jaw. Its lateral fibres originate from the fascia of the cheek armour, the posterior fibres from the preoperculum, and the medial fibres from the hyomandibula and pterygoid. There is a continuity of origin across all the bony medial elements and it is not possible to differentiate individual muscle segments. The lower jaw insertion is somewhat complex (Fig. 2B). Prior to insertion the outer bloc of fibres bifurcates, one bundle inserting on the medial margin of the dentary, the other on the coronoid process. Both insertions are musculose. An inner slip of fibres, arising from the pterygoid is also differentiable from the anterior part of the main muscle mass. This muscle slip turns medially around the anterior border of the pterygoid to insert tendinously on the inner aspect of the dentary.

Lying medial to muscle b is a long, almost cylindrical muscle, $\mathbf{c}$, which originates from the hyomandibula; its anterior part passes medially below muscle a and inserts tendinously onto the premaxilla.

Medial to muscle c, and extending along the pterygoid, is a thin, narrowly triangular muscle (d, Figs 2B \& 3A). Its origin is from the hyomandibula and its insertion is into a complexly divided connective tissue sheet. This sheet has attachments to the ventral surface of the palatine, to the upper surface of the premaxilla, and to the dentary (Fig. 3A).

In Pterygoplichthys there is a tendinous insertion on the premaxilla, although the dorsal part of the muscle is firmly attached to the palatine. The mandibular trunk of the trigeminal nerve passes across the face of muscle c, to make a slight loop below it and attach to its ventral border by connective tissue. From this point the nerve curves downward into muscle b and passes between the bifurcation of that muscle into the dentary-anguloarticular foramen to innervate the outer tissues of the lower jaw. 


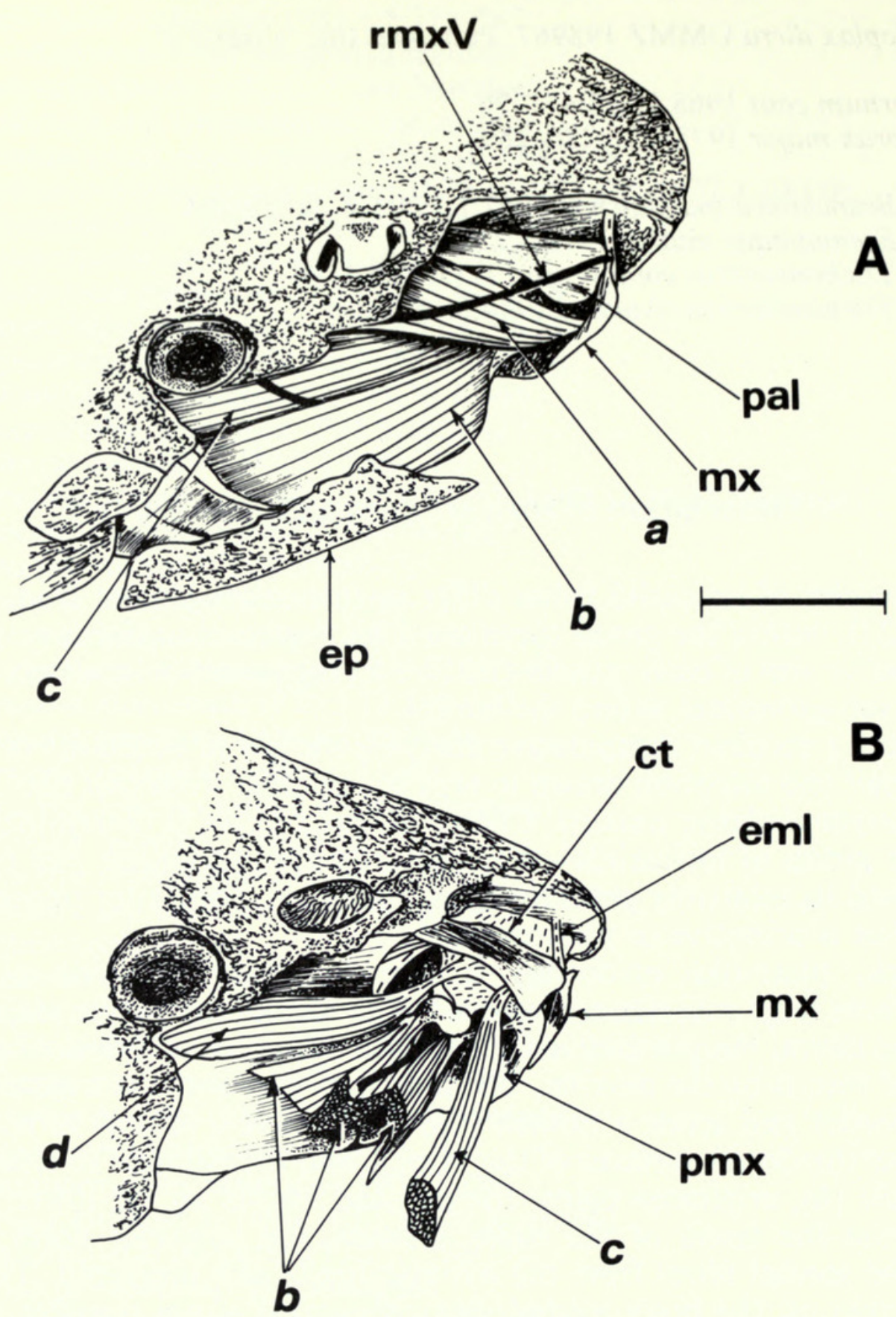

Fig. 2 Jaw muscles of Pterygoplichthys anisitsi (BMNH 1234.8.20: 255-64). A, superficial musculature, dorsal view; $B$, deeper muscles with muscle a removed, dorso-lateral view. Scale $=10 \mathrm{~mm}$. $\mathrm{eml}=$ ethmo-maxillary ligament: $\mathrm{ep}=$ epidermis; $\mathrm{pal}=$ palatine .

Muscles e and f (Fig. 3B) operate the palatine; muscle e originates from the medial face of the pterygoid and from the ventral surface of the lateral ethmoid, its insertion is onto the postero-ventral margin of the palatine. The fibres deriving from the pterygoid are horizontally aligned whereas those stemming from the lateral ethmoid are aligned at angles varying between $20^{\circ}-45^{\circ}$ to the horizontal. Muscle $\mathbf{f}$ originates from the ventro-medial surface of the lateral ethmoid and from the ventral surface of the frontal. It inserts on the posteromedial aspect of the palatine. A strong ligament connects the posterior lateral face of the palatine with the anterior border of the pterygoid.

In Pterygoplichthys muscle e lies in a pterygoid channel. The lateral wall of the channel rises to meet the lateral ethmoid margin and so totally encloses the muscle which exits through an anterior vertical slit. Alexander (1965) described a similar feature in Hypostomus.

Variants to the jaw muscle pattern described above occur in a group of taxa represented by Hemipsilichthys and Chaetostoma where muscle a is broadened and fan-like so that it completely covers muscle c (Fig. 4A). In species of this group the suspensorium is orientated into an almost horizontal plane, so that muscle b bulges laterally. 

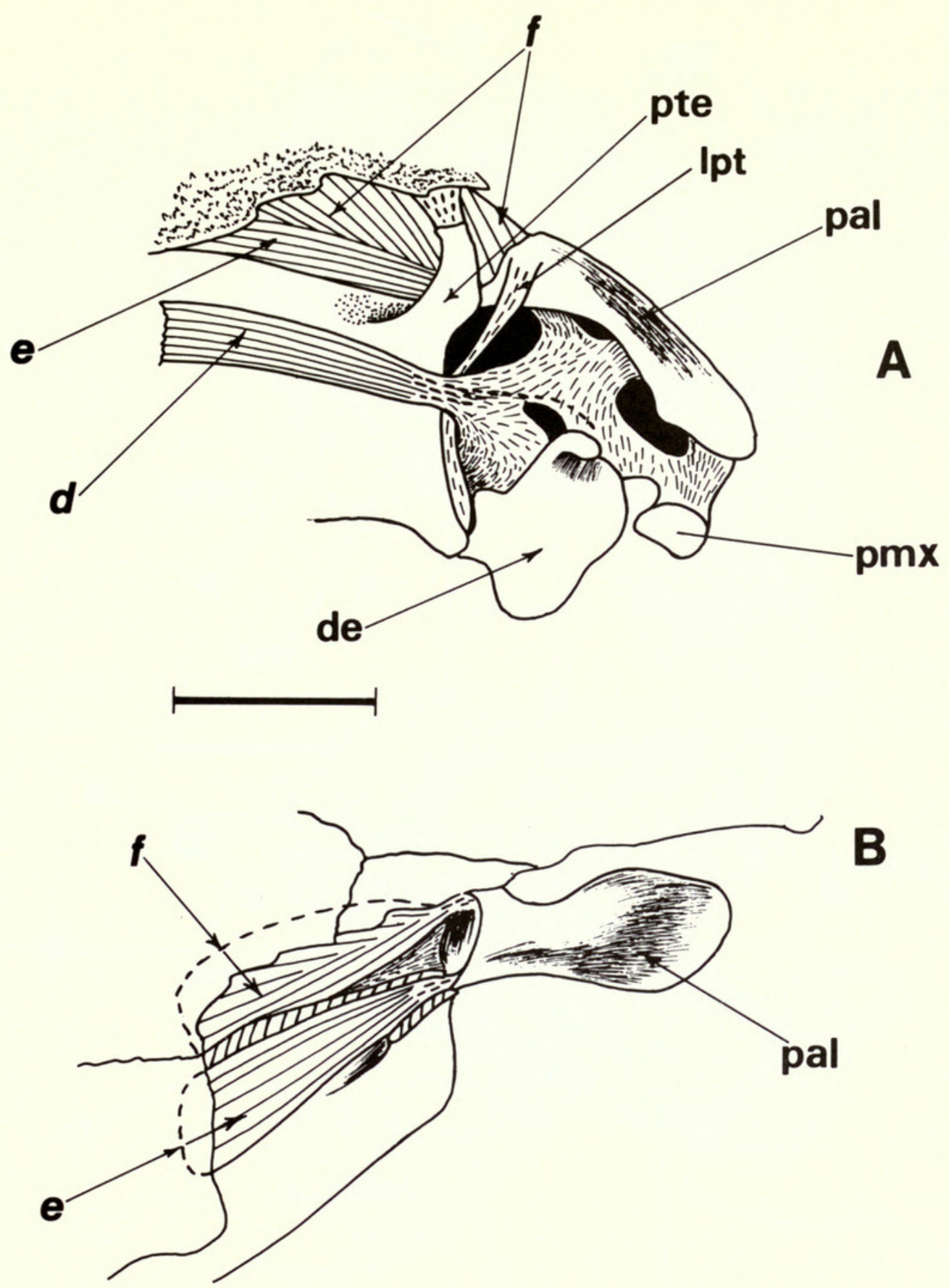

Fig. 3 Pterygoplichthys anisitsi, A, insertion of inner jaw muscle d, lateral view; B, configuration of extensor tentaculi muscle in dorsal view. The cut surfaces of the pterygoid are shown hatched. Scale $=3 \mathrm{~mm}$. lpt $=$ pterygoid-palatine ligament.

More marked differences occur in a group containing Loricaria, Sturisoma and Farlowella (Figs 5A; 6). Used here, Loricaria corresponds to the broad concept of Regan (1904) rather than the restricted one of Isbrücker (1981); see further discussion on p. 338. In these genera muscle $\mathbf{c}$ inserts on the premaxilla via a thick tendon whose length is correlated with that of the snout. The tendon passes through a loop of connective tissue at the rostro-ventral margin of the palatine, to turn through a right angle before its premaxillary insertion (Fig. 6 , tc). Muscle $\mathbf{d}$ is directed medially, its tendon of insertion running into the palatinepremaxillary connective tissue and almost meeting its antimere in the midline before joining the premaxilla. In Sturisoma, the muscle is attached to the ventro-posterior part of the palatine as in Pterygoplichthys.

In some Loricaria species there are distinct dorsal and ventral portions of muscle a. The lower portion (av, Fig. 5A) inserts on the wide, convex dorsal surface of the palatine, its postero-medial fibres are inseparable from those of muscle e; the upper part (ad) runs forward to insert on the maxilla as in other loricariid taxa. 

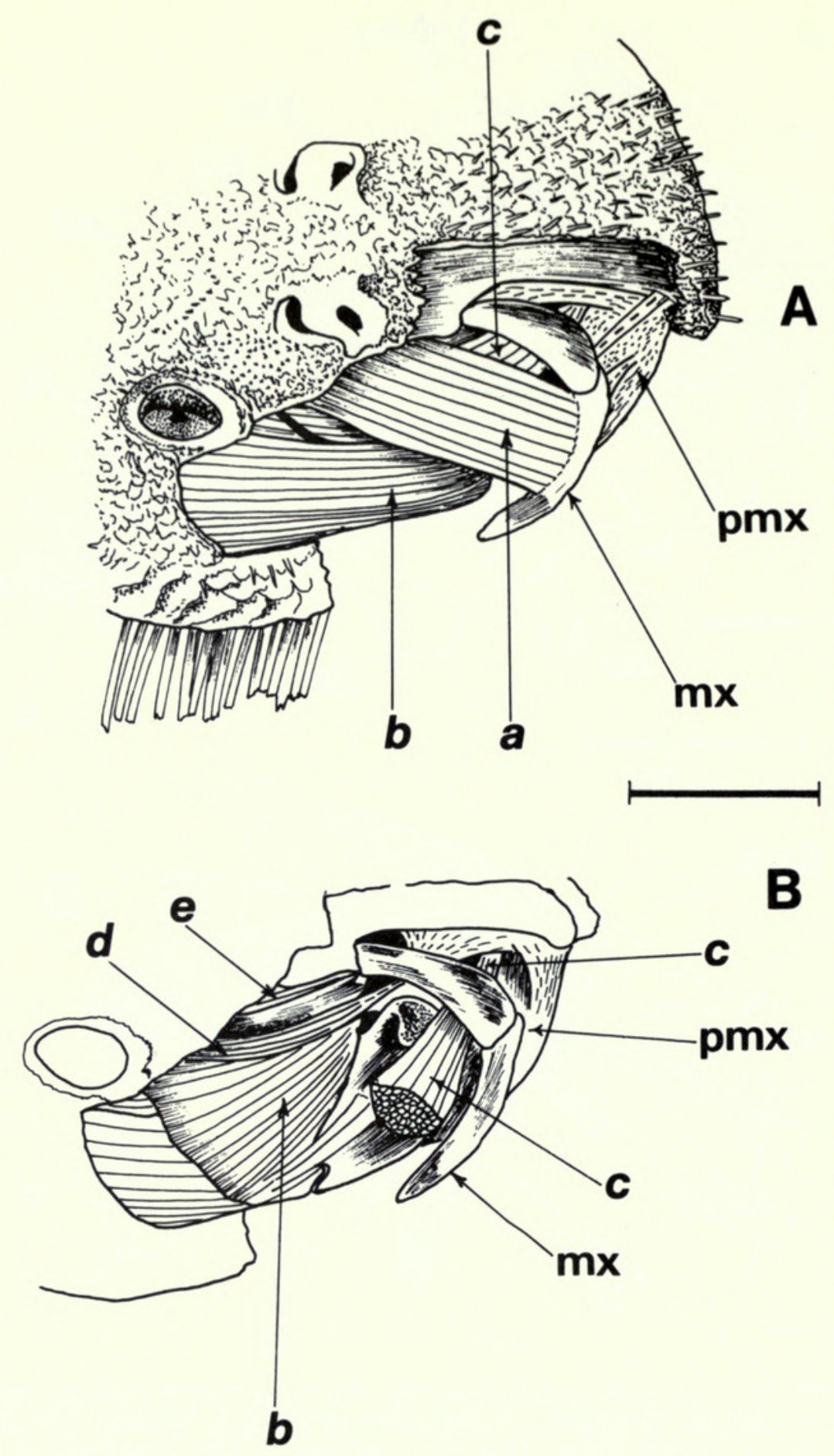

Fig. 4 Hemipsilichthys calmoni (BMNH 1929.2.1: 66-71). A, superficial musculature; B, deeper muscles with muscle a removed; both in dorsal view. Scale $=10 \mathrm{~mm}$.

Farlowella differs from Loricaria and Sturisoma in that muscle a is enclosed within a pterygoid channel similar to that in Pterygoplichthys. Pseudohemiodon and Hemiodonichthys depart in several respects from the above arrangements (Fig. 5B). Muscle $\mathbf{a}$ is a narrow, straplike element; muscle c does not insert directly on the maxilla but runs into an extensive tissue sheet connecting the pterygoid, palatine, premaxilla and maxilla; muscle d inserts, via a long tendon, on the premaxilla and maxilla; muscle e inserts tendinously onto the ventral centre of the lamellate palatine.

Two other genera which depart from the generalized jaw muscle plan are Hypoptopoma and Otocinclus (Fig. 7). In these genera, muscle a occurs as the most lateral of the superficial jaw muscles. It runs from the laterally shifted lateral ethmoid (see p. 332) to insert tendinously into the centre of the maxilla. Muscles $\mathbf{b}$ and $\mathbf{c}$ have their 'normal' insertions onto the lower jaw and premaxilla respectively. Muscle d joins a thick connective tissue band linking the palatine and premaxilla. 


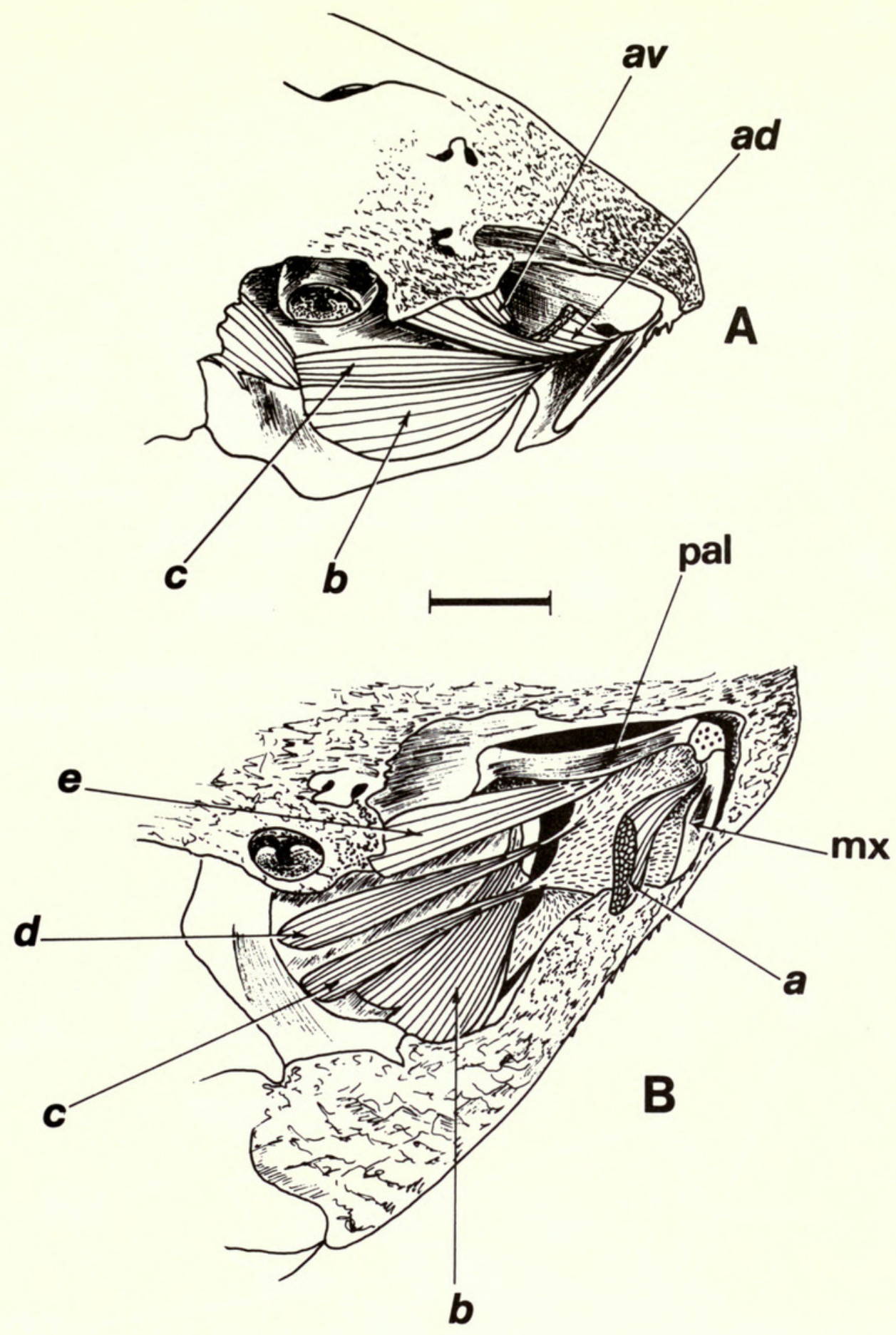

Fig. 5 Jaw and palatine muscles of A, Loricaria strigilata (BMNH 1929.2.1: 31-40) in dorso-lateral view; B, Pseudohemiodon sp. (uncatalogued) in dorsal view. Scale $=5 \mathrm{~mm}$.

\section{Hyoid muscles}

The muscles serving the lower jaw, and having their origins from the hyoid bar, have a uniform morphology in the Loricariidae.

The intermandibularis is relatively feeble compared with that in other siluroids. It is most highly developed in Pterygoplichthys (Fig. 8A) where its lateral insertion is bifurcate, the inner part joining the dentary, the outer attaching to the loose connective tissue at the rictus of the mouth. In other loricariid taxa the intermandibularis is a thin band of muscle fibres which in broad-mouthed genera, e.g. Chaetostoma, Pseudancistrus, Lipopterichthys, attaches laterally to the reflected lip tissue (Fig. 8B). 


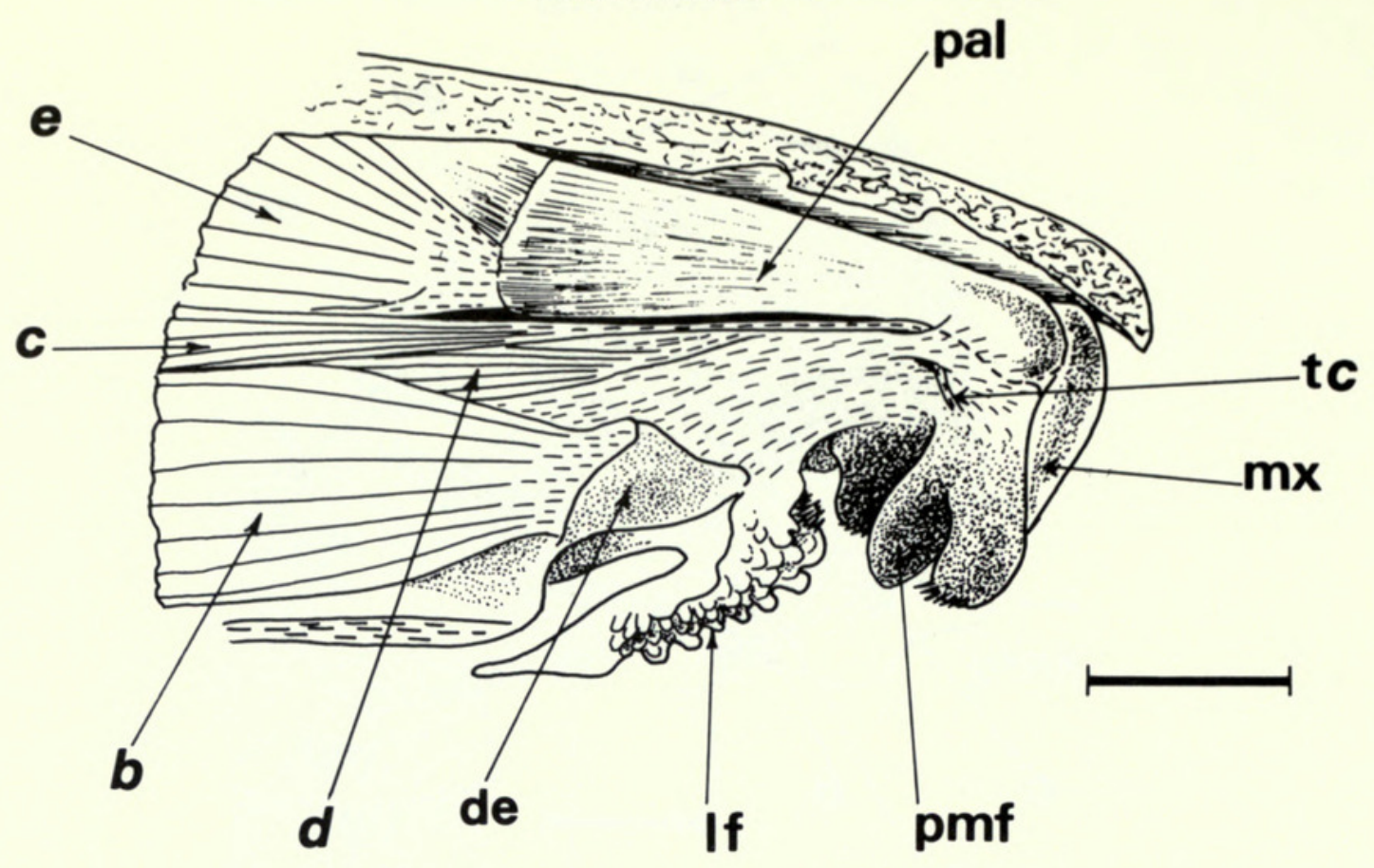

Fig. 6 Metaloricaria nysseni (BMNH 1982.4.7:7) showing insertions of deeper muscles; lateral view. If = lower labial tissue; $\mathrm{pmf}=$ premaxillary medial labial fold; $\mathrm{tc}=$ insertion tendon of muscle $\mathbf{c}$. Scale $=5 \mathrm{~mm}$.

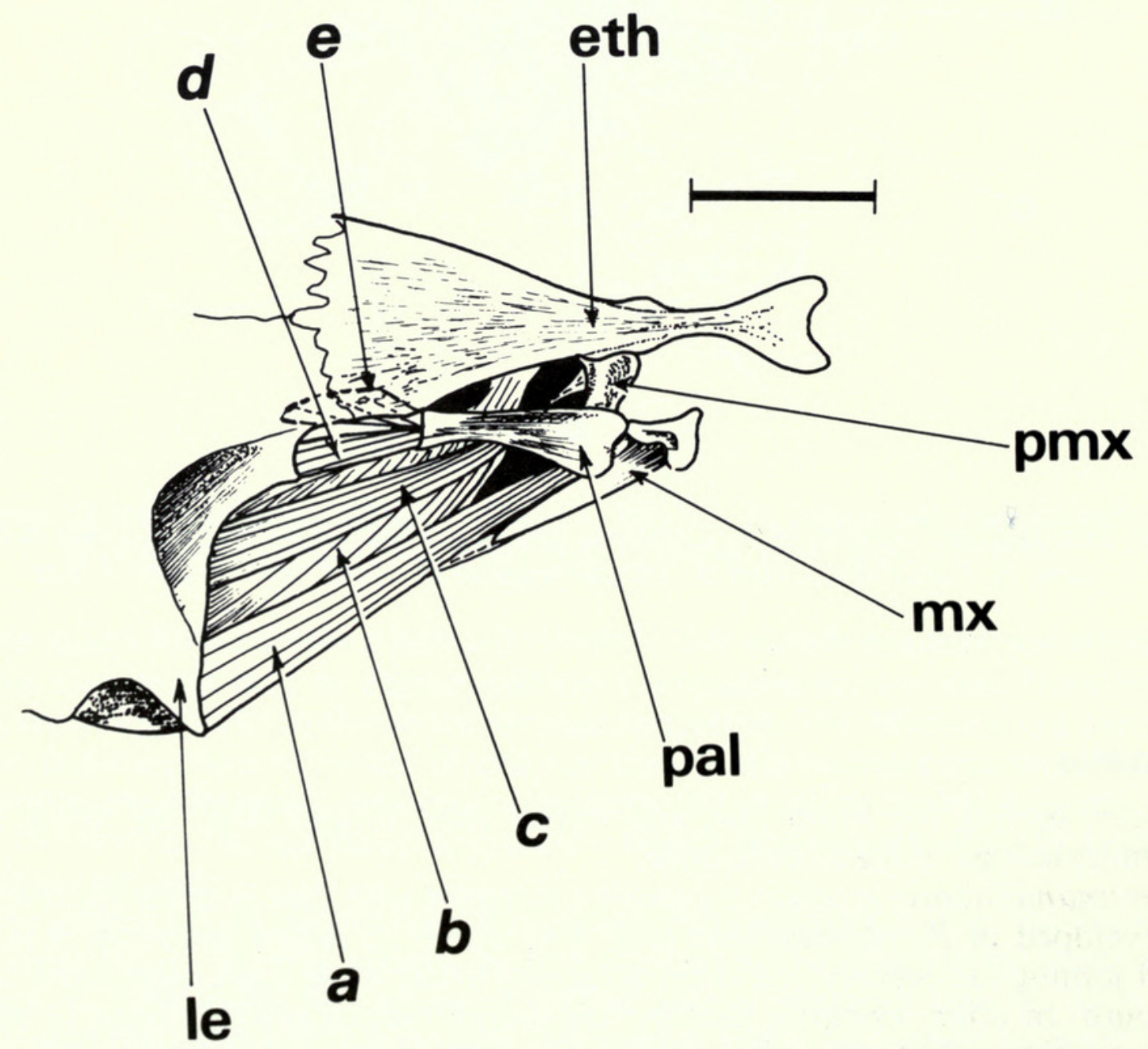

Fig. 7 Hypoptopoma carinatum (BMNH 1973.3.27: 3) jaw muscles in dorsal view. Scale $=1 \mathrm{~mm}$. 


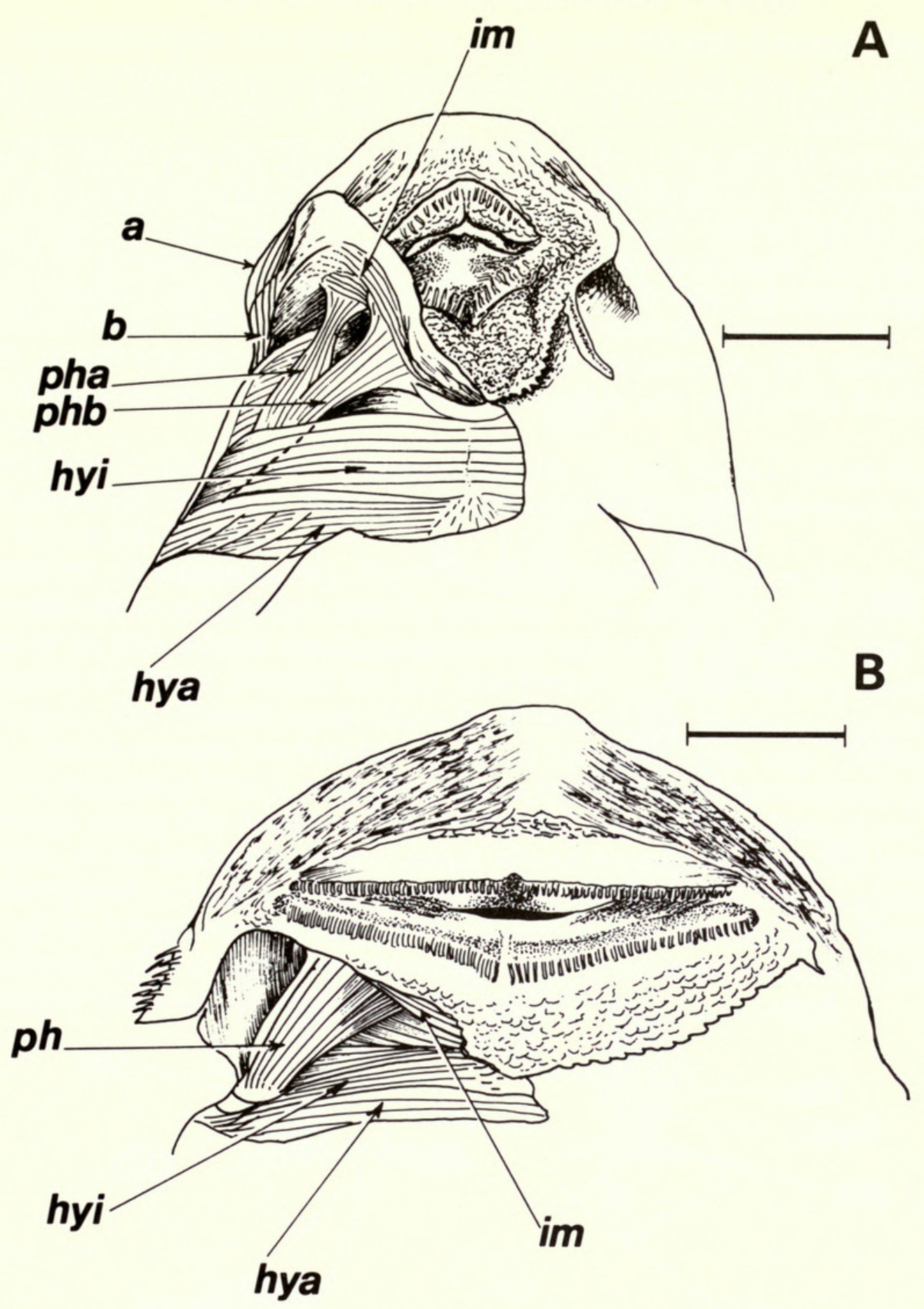

Fig. 8 Hyoid muscles of A, Pterygoplichthys anisitsi (BMNH 1934.8.20: 255-64); B, Chaetostoma acquinoctialis (BMNH 1978.7.14: 20), both in ventral views. Scales $=5 \mathrm{~mm}$. ph, $\mathbf{a}, \mathbf{b}=$ divisions of protractor hyoidei; $\mathbf{h y a}, \mathbf{h y i}=$ hyohyoideus adductores and inferioris; $\mathbf{i m}=$ intermandibularis .

The protractor hyoideus is well-developed and extends between the posterohyal and anterohyal to the lower jaw (Fig. 8A). The fibres from the left and right hyoid bars do not meet in the midline as in other siluroids and indeed, in most teleosts. Each part of the muscle is divided for almost its entire length into two segments (Pha, Phb, Fig. 8A). One lies dorsomedially and attaches to the dentary, the other is ventro-lateral and attaches to the dorsal face of the reflected lip tissue.

The largest hyoid muscle in loricariids is the hyohyoides inferioris which extends laterally from the midline of the urohyal to the anterohyal and posterohyal. In Cochliodon, Panaque and Hypostomus, the lateral border of the muscle has a marked concave indentation to allow for the bypass of the protractor hyoideus. The hyohyoidei adductores extend from the upper medial face of the operculum, between the branchiostegal rays, to a midline raphe above the sternohyoideus. 


\section{Opercular and suspensorial muscles}

The muscles having the greatest degree of variability in size and position are those controlling the opercular apparatus.

In Pterygoplichthys the dilatator operculi muscle is a thin, narrow element running along a hyomandibular groove. It originates from a pterotic fossa and inserts on the antero-medial border of the operculum (do Fig. 9A). The levator operculi muscle originates from the pterotic-posttemporal = temporal plate of Regan, 1904, and inserts on the dorso-medial margin of the operculum (lo, Fig. 9A). The adductor operculi originates from a cavity formed
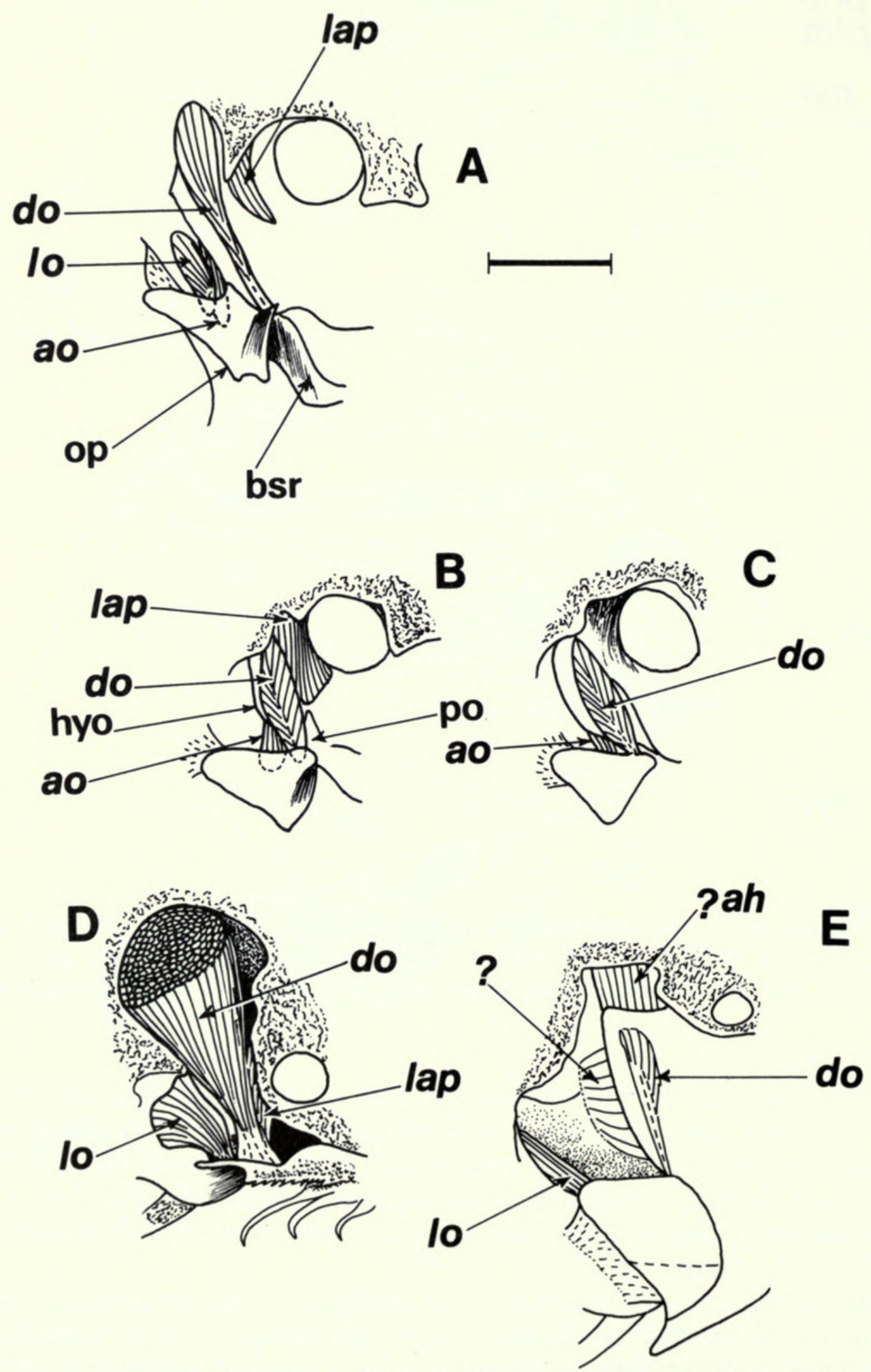

Fig. 9 Opercular and suspensorial muscles of A, Pterygoplichthys anisitsi; B, Loricaria simillima; C, Loricaria cataphracta; D, Ancistrus occidentalis; E, Pseudohemiodon sp. Scale $=5 \mathrm{~mm}$. A-D in dorso-lateral, $\mathrm{E}$ in dorsal views. $\mathbf{a h}=$ adductor hyomandibularis; $\mathrm{po}=$ preoperculum; $\mathrm{bsr}=$ branchiostegal ray. 
between the hyomandibula and pterotic, to run almost vertically behind the hyomandibula and insert on the central dorso-medial aspect of the operculum (ao, Fig. 9A).

In Pterygoplichthys the levator arcus palatini is a thin, vertically aligned muscle extending between the sphenotic and hyomandibula (lap, Fig. 9A). The adductor arcus palatini muscle in all loricariids examined runs laterally and almost horizontally from the posterior part of the parasphenoid to the medial face of the hyomandibula. It is probably more correct to refer to this muscle as the adductor hyomandibulae (see Winterbottom, 1974: 239) as it is a separate element from the anterior part of the adductor arcus palatini which is modified, as in most siluroids, to form the extensor tentacularis muscles (see p. 328).

Apart from minor variations in the orientation of the muscles, the above descriptions of opercular and suspensorial muscles in Pterygoplichthys are applicable to Hypostomus and Hemiancistrus.

In Neoplecostomus, the dilatator operculi inserts on the dorsal rather than the anterior aspect of the opercular margin. The interoperculum in Neoplecostomus is also larger than that in other loricariid genera.

Pseudacanthicus, Pseudancistrus, Stoniella, Cochliodon and Panaque show a departure from the hypostomine opercular muscle pattern. The dilatator operculi is shifted more anteriorly so as to run across the posteromedial aspect of the orbit. The muscle passes, laterally, beneath a bridge formed by the preoperculum and pterotic-posttemporal plate before inserting on the reduced operculum. In Panaque the dilatator operculi is situated so far anteriorly that it crosses the medial centre of the orbit (Fig. 10). In these five taxa the levator operculi originates from a ventral cavity in the pterotic-posttemporal plate and inserts via a thin tendon along the thickened dorso-medial edge of the operculum. The adductor operculi appears to be represented by a small slip of muscle running horizontally from the pterotic-posttemporal to insert on the posterior border of the preoperculum, thus running along the top of the bridge beneath which the dilatator operculi emerges. There is no connection of the adductor operculi with the operculum. In Pseudacanthicus, Stoniella and Panaque there are evertible 'interopercular' spines (see p. 334).

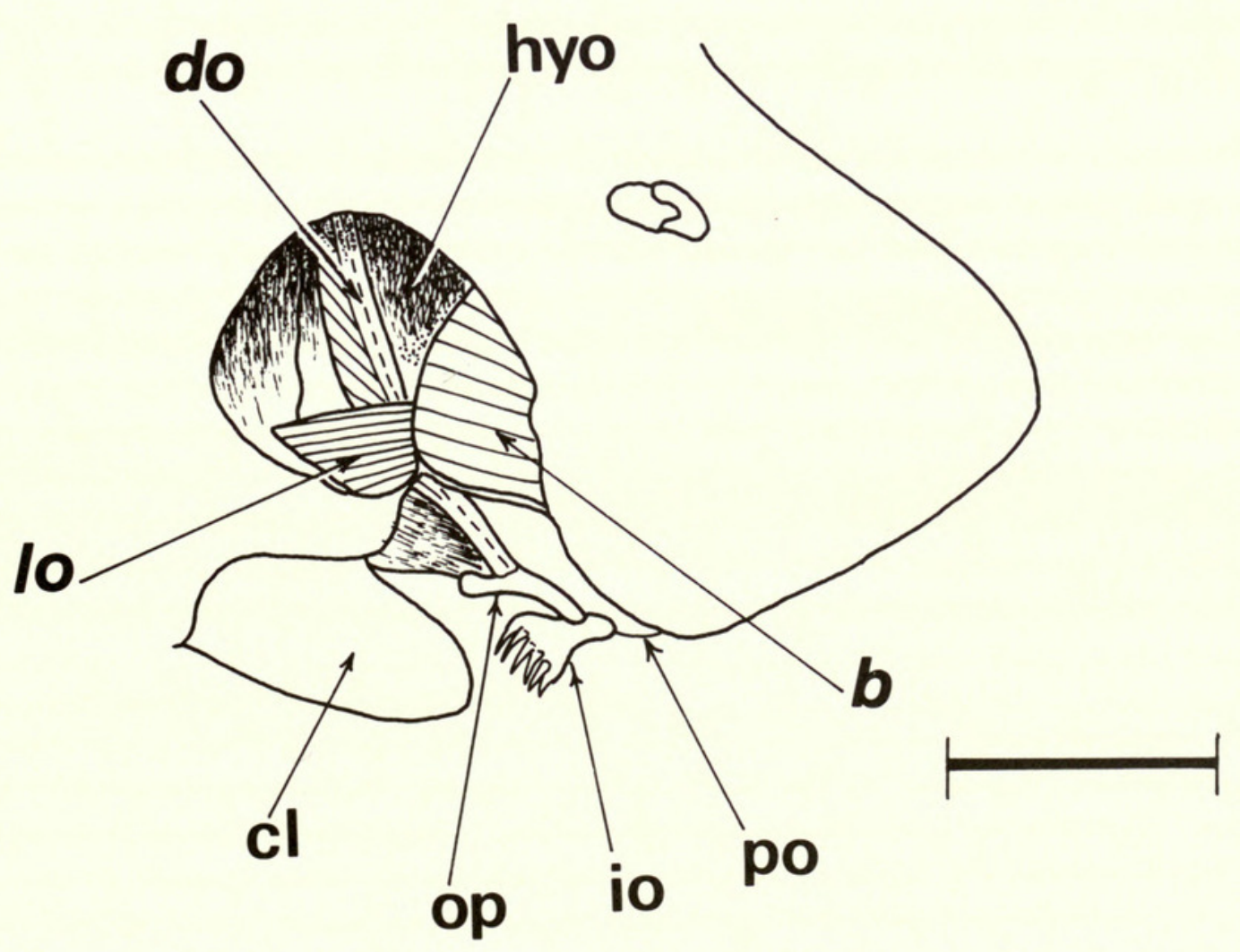

Fig. 10 Opercular muscles of Panaque nigrolineatus (BMNH 1974.8.4: 13-15), in lateral view. $\mathrm{Scale}=10 \mathrm{~mm}$. $\mathrm{cl}=$ cleithrum; io = interoperculum; hyo = hyomandibula; $\mathrm{po}=$ preoperculum. 
In Hemipsilichthys and Chaetostoma the dilatator operculi is thin and tendinous. It originates from the pterotic and runs outward at an angle of $30^{\circ}$ to the horizontal in a lateral hyomandibular groove. The adductor and levator operculi muscles are of similar morphology to those in Pterygoplichthys. The levator arcus palatini is, however, smaller, occupying a postorbital space between the sphenotic and hyomandibula.

In Ancistrus the opercular muscles are hypertrophied. The dilatator operculi muscle is extensive, originating from the roof of the cranium and the supraoccipital (Fig. 9D). The central tendon runs antero-laterally at an angle of about $45^{\circ} \mathrm{c}$ to the vertical and attaches to the postero-dorsal aspect of the operculum. The operculum is modified to form a mechanism for rotating the 'interoperculum' laterally; described below (p. 334).

The levator and adductor operculi muscles are well developed, the adductor originating from a ventral process of the fused vertebral complex and directed ventro-laterally at $35^{\circ}$ to the vertical. The levator arcus palatini, instead of inserting on the suspensorium, as in other loricariids, joins the insertion tendon of the dilatator operculi and thus appears to reinforce the adduction of the operculum.

In Loricaria and Sturisoma, the dilatator operculi originates principally from the hyomandibula, a few antero-ventral fibres take their origin from the posterior rim of the preoperculum. In some species of Loricaria, e.g. L. simillima, the muscle's origin is shared in part with that of the levator arcus palatini which is also well developed (Fig. 9B). In other species, e.g. L. cataphracta, the levator arcus palatini is absent (Fig. 9C).

In all Loricaria species examined the levator operuli is absent; the adductor operculi originates from a pterotic-posttemporal cavity. In Sturisoma a few tendinous fibres passing along the dorso-medial surface of the operculum may represent the levator operculi, and the adductor operculi may be represented by a few fibres emanating from the anterior fascia of the body musculature, which at this point is directed laterally to insert on the pteroticposttemporal plate.

Farlowella possesses a similar morphology of the dilatator operculi and levator arcus palatini muscles to that of Loricaria. In this genus both adductor and levator operculi muscles are present but weakly developed.

In Pseudohemiodon and Hemiodonichthys the dilatator operculi is reduced virtually to a tendon which runs in a lateral hyomandibular groove. Insertion is on to the antero-dorsal corner of the operculum. Levator and adductor operculi muscles are absent. Instead, the medial wall of the operculum provides the site of attachment for lateral fibres of the hyohyoideus adductores muscle (9E). There is no levator arcus palatini muscle in these taxa.

Hypoptopoma and Otocinclus both have a feeble dilatator operculi originating from the hyomandibula and inserting on the antero-dorsal point of the operculum. A levator operculi is present but weakly developed and runs forward ventro-laterally from a medial fascia of the epaxial musculature.

The levator arcus palatini originates from a sphenotic fossa, runs outward at an angle of $45^{\circ}$ to the vertical and inserts on the hyomandibula just anterior to the ventral part of the dilatator operculi.

\section{Summary of muscle systems}

From the data presented above, the following groups of loricariid catfishes are discernible on the basis of correlated myological features:

1. Jaw muscles: muscle a narrow, band-like, lying straight and lateral to the mesethmoid, inserting on the maxilla; muscle $\mathbf{b}$ inserting entirely on the lower jaw; muscle $\mathbf{c}$ inserting on the premaxilla; muscle $\mathbf{d}$ inserting on the premaxilla via a connective tissue sheet which attaches to the dentary and the palatine; muscle e running through a well-developed pterygoid channel to insert on the palatine. Opercular muscles: usually well-developed; levator arcus palatini (LAP) small. Hyoid muscles: intermandibularis well-developed, sometimes bifurcated laterally, hyohyoidei inferioris with concave lateral border, protractor hyoideus 
with bifurcate insertion to the lower jaw, hyohyoidei adductores attaching to the medial face of the operculum.

Included genera: Neoplecostomus, Hypostomus, Pterygoplichthys, Hemiancistrus.

2. Jaw and hyoid muscles as (1). Opercular muscles: dilatator operculi shifted anteriorly medial to orbit; adductor operculi bridges pterotic-posttemporal plate and preoperculum. Included genera: Panaque, Cochliodon.

3. Jaw and hyoid muscles as (1), but no pterygoid channel accommodating muscle e. Opercular muscles as (2).

Included genera: Stoniella, Pseudacanthicus, Pseudancistrus, Acanthicus.

4. Jaw and hyoid muscles as (1), but muscle a expanded concomitantly with increased maxillary length; muscle e running in pterygoid channel. Opercular muscles: dilatator operculi mostly tendinous and obliquely angled laterally. LAP considerably reduced.

Included genera: Hemipsilichthys, Lipopterichthys, Chaetostoma, Lasiancistrus.

5. Jaw and hyoid muscles as (1). Opercular muscles hypertrophied, dilatator operculi originating from supraoccipital, levator operculi from the complex vertebrae.

Included genera: Ancistrus, Lithoxus.

6. Jaw and hyoid muscles as (1), but muscle d directed medially, its tendon of insertion almost meeting its antimere; muscle a in some Loricaria partly inserting on palatine; muscle e in Farlowella and Loricaria platystoma enclosed in a pterygoid tunnel. Opercular muscles: dilatator operculi variably developed; levator and adductor operculi muscles always reduced, sometimes absent. LAP absent in some Loricaria species.

Included genera: Loricaria, Farlowella, Sturisoma.

7. Jaw and hyoid muscles as in (1), but muscle d with long insertion tendon; muscle e inserting into the centre of the palatine ventrally. Opercular muscles reduced, levator and adductor operculi absent. LAP absent.

Included genera: Pseudohemiodon, Hemiodonichthys, Crossoloricaria.

8. Jaw muscles differ from all the above in that muscle a lies laterally to the other adductor musculature, otherwise as in (1). Opercular muscles reduced.

Included genera: Hypoptopoma, Otocinclus.

\section{Out-group comparisons and homologies of loricarioid jaw muscles}

A broad comparison of siluroid jaw muscles is presented elsewhere (Howes, 1983) and analysis is here restricted to the following taxa:

Diplomystes, the single genus comprising the family Diplomystidae, considered by most authors to be the most 'primitive' extant siluroid.

Nematogenys, the single genus comprising the family Nematogenyidae. Recent authors, Gosline (1945), Chardon (1968), Arratia et al. (1978) include this genus within the Trichomycteridae. For reasons given here (p. 329), I follow Eigenmann (1928) in recognising the genus as representing a distinct family.

Astroblepus, the single genus comprising the family Astroblepidae. Regan (1911) and Gosline (1947) both considered the astroblepids a subfamily of the Loricariidae. I follow Eigenmann (1910) in regarding them as a distinct family (see p. 341). Differences in dentition and cranial osteology suggest that there are possibly two genera contained within Astroblepus.

Representatives of the Trichomycteridae and Callichthyidae, both families believed by Chardon (1968) to be related to loricarioids. The terms 'loricarioid' refers to the members of the Loricariidae plus the Astroblepidae, and 'loricariid' to members of Loricariidae only.

In the majority of siluroids the adductor mandibulae inserts on the lower jaw. Plesiomorphically, as in Diplomystes and Nematogenys, divisions of the muscle block are absent or poorly differentiated. The outer, most massive part of the muscle originates from the preoperculum, hyomandibula and usually the quadrate, and inserts onto the outer face of the anguloarticular-dentary. This arrangement has been found in all siluroids examined and it 
was the contention of Fink \& Fink (1981) that a lower jaw insertion of the outer part of the muscle $\left(A_{1}\right)$ was an apomorph character of siluroids (but see below, p. 327).

Although in loricariids a major portion of the adductor mandibulae, termed muscle $\mathbf{b}$ in this text, does insert on the lower jaw, medial portions, muscles $\mathbf{c}$ and $\mathbf{d}$, pass via thin tendons running through the palatal connective tissue to the premaxilla (see Fig. 3A).

As stated by Alexander (1965: 135), in the Callichthyidae the superficial part of the adductor mandibulae, which he believed to be a combined $\mathrm{A}_{1}+\mathrm{A}_{2}$, inserts partly on the lower jaw and partly on the anguloarticular-maxillary ligament, whilst a medial part inserts on the outer face of the lower jaw. The situation is rather more complex than that outlined by Alexander since the dorsal part of the adductor can be distinguished as a separate element. Thus, the adductor morphology in callichthyids may be described as follows: An element originating from the hyomandibula, just postero-ventral to the orbit, inserts tendinously on the antero-medial process of the maxilla (rt, Fig. 11). The larger part of the adductor originates posteriorly from the preoperculum, medially from the hyomandibula and laterally from the 3 rd infraorbital. Its antero-ventral fibres insert on the medial and dorsal aspects of the anguloarticular, the dorsal fibres share the points of insertion on the maxilla with those of the more dorsal muscle, ?A $\mathrm{A}_{1}$ (Fig. 11B). As noted above, the deeper part of the muscle inserts entirely on the lateral face and dorsal margin of the anguloarticular.

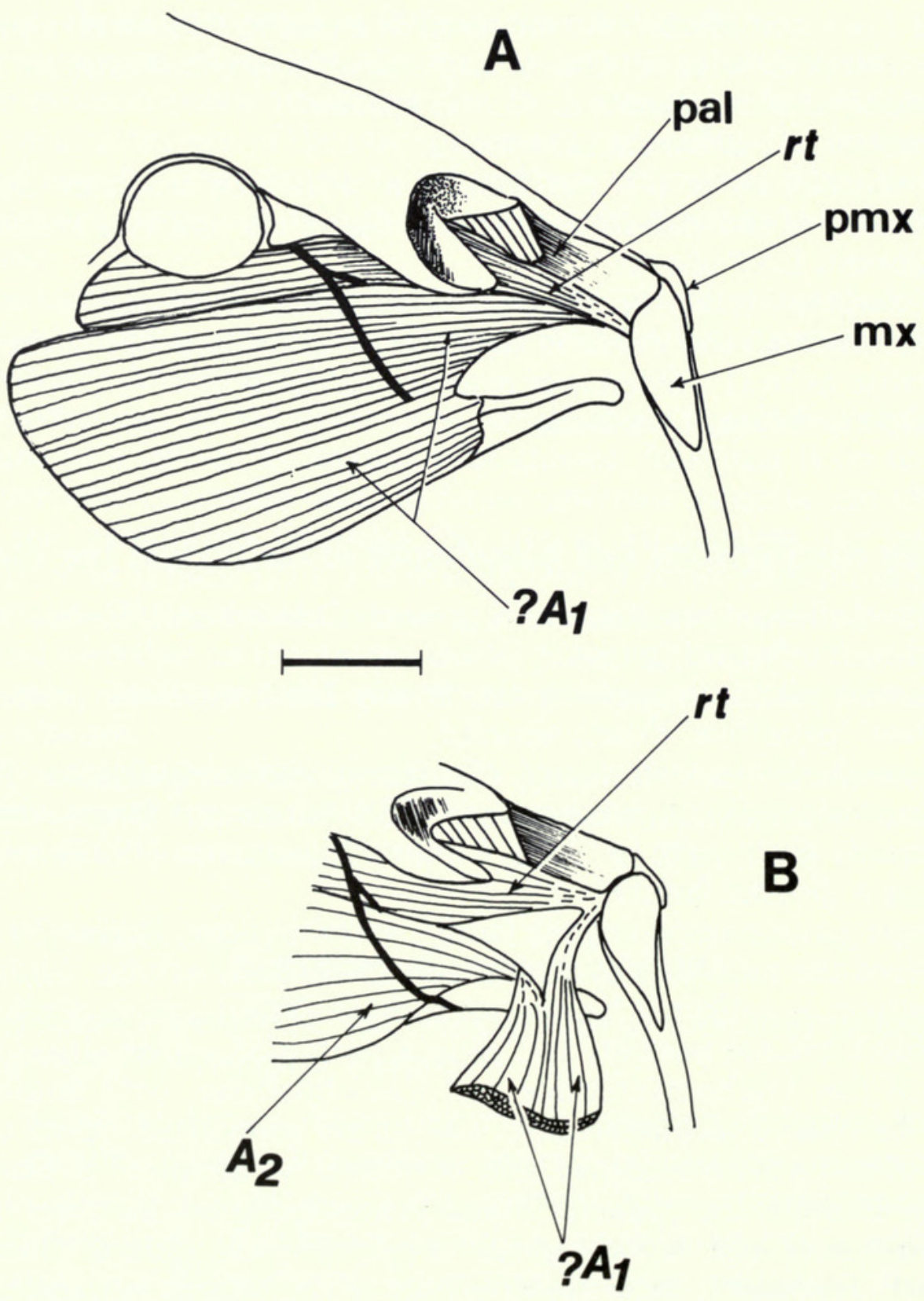

Fig. 11 Jaw muscles of Hoplosternum littorale (BMNH 19434.9.12: 413-420). A, superficial musculature; $\mathrm{B}$, deep muscles; both in lateral view, $\mathrm{Scale}=5 \mathrm{~mm} . \mathbf{r t}=$ retractor tentaculi. 
As in loricariids, the superficial part of the principal muscle is separated from its medial portion by the ramus mandibularis nerve trunk. In this respect, the outer portion, which has its insertion on the upper and lower jaws, should be considered as $\mathrm{A}_{1}$; whilst the medial part having its insertion entirely on the lower jaw should be considered as $A_{2}$. The dorsal muscle, which has its insertion on the maxilla, is equivalent to the retractor tentaculi in loricariids and other siluroids, except that its origin is posterior rather than anterior to the orbit. That this muscle appears to be a dorso-medial part of the adductor, lends credence to the idea that phylogenetically, the retractor tentaculi originated from a medial part of the adductor muscle complex (see Alexander, 1965; Howes, 1983).

In Diplomystes and Nematogenys the adductor mandibulae is relatively undifferentiated, the outer part of the muscle running on to the lateral aspect of the anguloarticular, its dorsal fibres inserting via a thick tendon on to the dorsal rim of the dentary. The tendon is continuous with a thick 'ligamentous' tissue attaching to the maxilla (see Howes, 1983).

In the Trichomycteridae, the adductor mandibulae is also relatively simple (Fig. 12A).
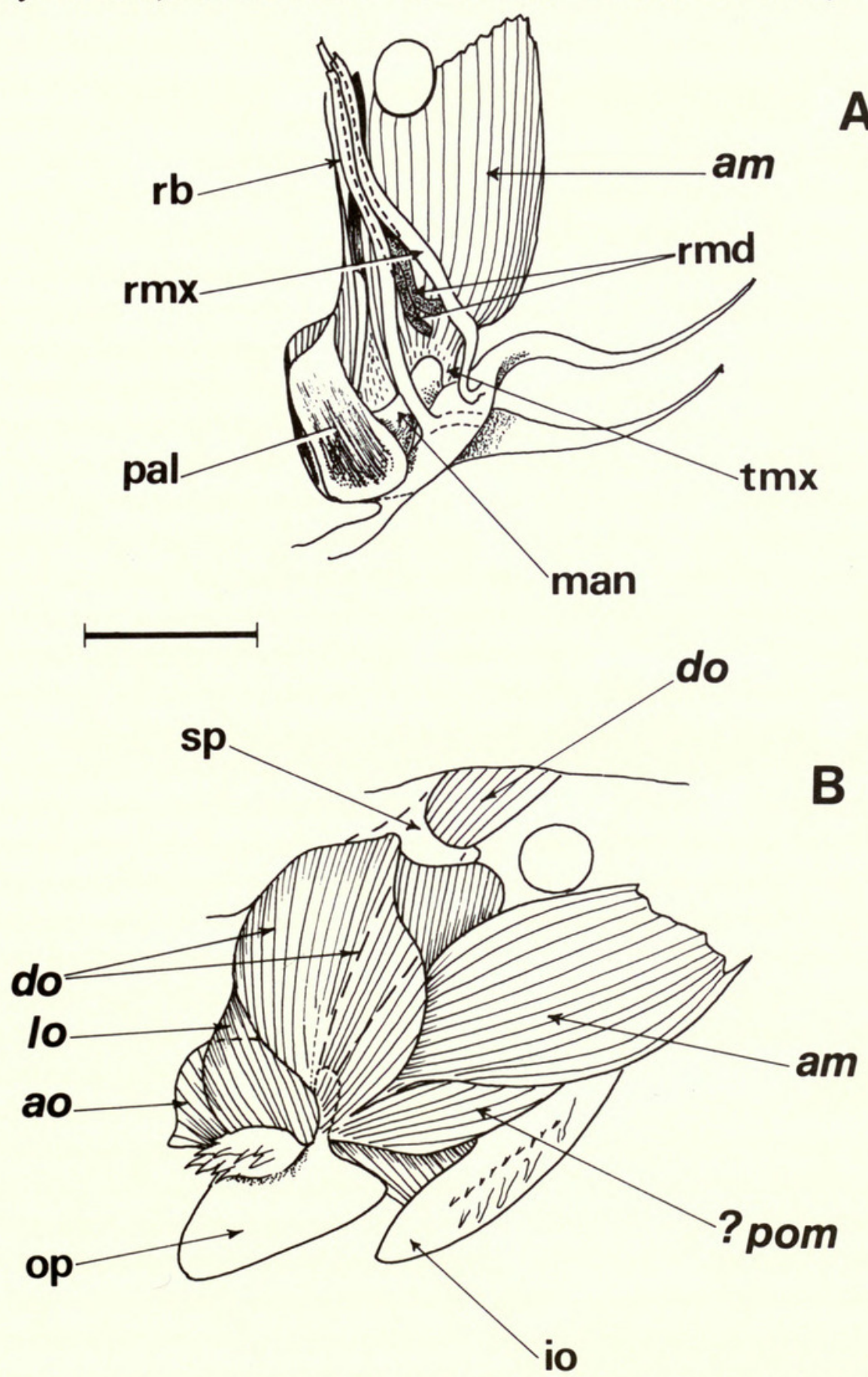

Fig. 12 Trichomycterus rivulatus (BMNH 1944.6.16: 142-45). A, superficial jaw muscles in dorsal view. B, posterior jaw and opercular muscles, la lateral view. Scale $=5 \mathrm{~mm}$. am =adductor mandibulae; pom = preopercular muscle; $\operatorname{man}=$ mandible; $\mathrm{rb}=$ buccal ramus of facial nerve; $\mathrm{rmd}=$ mandibularis nerve; $\mathrm{sp}=$ sphenotic; $\operatorname{tmx}=$ tendon of adductor muscle to maxilla. 
The outer portion inserts on the lower jaw but a tendon runs forward into connective tissue attaching to the maxilla. A medial section of the muscle, ? $\mathrm{A}_{2}$, inserts into the inner aspects of the dentary.

In the Astroblepidae, the adductor mandibulae, muscle $\mathbf{b}$, is as in the Loricariidae, with the outer portion being divided from the inner by the mandibularis nerve (Figs 13A \& B). The outer portion inserts on the rim of the anguloarticular, whilst the inner inserts on the medial face of the dentary. Muscle $\mathbf{c}$ is also present but is deeper and thicker in the Loricariidae. Two portions of this muscle are discernible, a broad dorsal segment and a deep medial one. The ventral fibres of the medial segment originate from the inner part of the muscle $\mathbf{b}$, the remainder from the ptergyoid. The dorsal fibres of the upper portion originate from the lateral ethmoid and the ptyergoid. Medially the two portions are inseparable but insert on short, separate tendons which join prior to their insertion on the premaxilla (Fig. 13B).
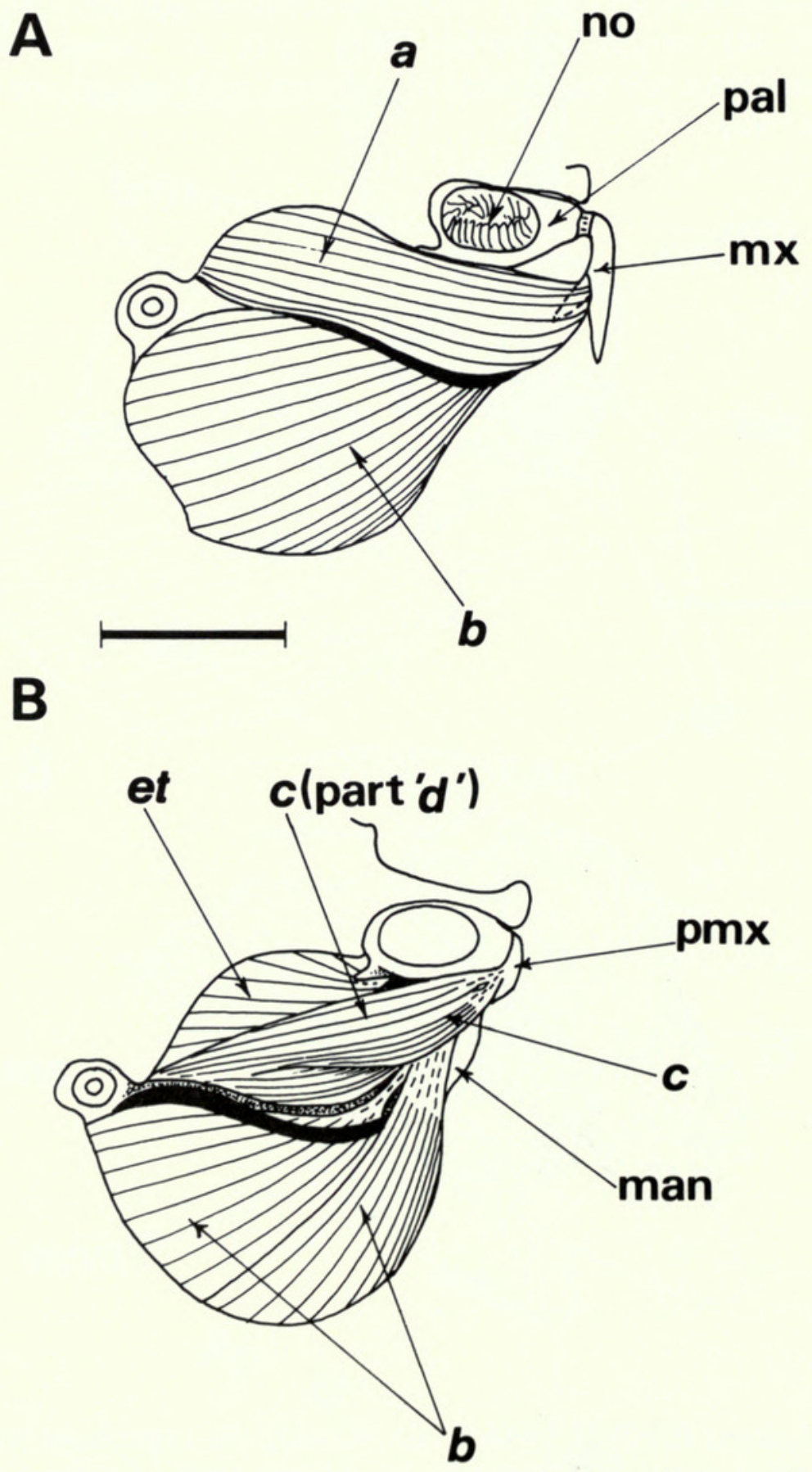

Fig. 13 Astroblepus cf. praeliorum (BMNH 1969.1.27: 35-46). A, superficial jaw musculature; B, deep muscles, both in dorsal view. Scale $=5 \mathrm{~mm}$. man-mandible; no $=$ nasal organ. 
The morphology of the adductor mandibulae in other siluroids is discussed elsewhere (Howes, 1983), but it is pertinent to note here that in none is there a direct connection between the upper jaw and the outer muscle element. It is also argued (Howes, 1983) that this condition is plesiomorphic for otophysans, and that encroachment of lateral fibres to the upper jaw is a derived feature.

The premaxillary insertion of part of the adductor mandibulae in the Loricariidae and Astroblepidae, and its maxillary insertion in the Callichthyidae, are viewed as apomorph features. In all three groups, the articulation between the premaxilla and the mesethmoid is a mobile one, a condition not encountered elsewhere in siluroids. In other siluroids, including Diplomystes, the premaxilla is firmly united to the lateral extensions of the mesethmoid. Alexander (1965: 134) showed that in Corydoras the mouth is protrusile, and this protusibility is partly the result of having a movable premaxilla. It seems likely that because of its restricted distribution amongst siluroids, a movable ethmoid-premaxillary joint is more likely to be a derived character, particularly if Diplomystes is viewed as the most plesiomorph extant siluroid (see Fink \& Fink, 1981). Suffice it to say that in other otophysans, mobile premaxillary-ethmoid articulations are regarded as derived characters (see Vari, 1979: 272 concerning characoids).

If the plesiomorph conditions of adductor mandibulae $\mathrm{A}_{1}$ in teleosts is regarded as that in which the muscle is inserted on the lower jaw and lies lateral to the mandibular nerve trunk, then muscle $\mathbf{b}$ in loricariids and astroblepids must be the homologue of $A_{1}$. This pattern is, however, further complicated in these two groups by the mandibular nerve trunk entering the muscle mass and passing between two bundles of fibres before entering the lower jaw (see p. 313). Thus, on the strict definition given above, those fibres lying medial to the nerve trunk must be regarded as $A_{2}$. This suggestion is supported by the insertion of the medial fibres of muscle $\mathbf{b}$ on to the coronoid process and medial face of the dentary-which is the usual place of insertion for $\mathrm{A}_{2}$. Whether the inner slip which in loricariids inserts on the medial face of the dentary should be regarded as $A_{3}$ is doubtful, as by definition, $A_{3}$ inserts on the anguloarticular. However, it must be borne in mind that the loricariid lower jaw has rotated outward so that the inner surface has come to lie in a horizontal plane with the dentigerous surface forming the anterior border. It may be that coordinate with this rotation, the ' $\mathrm{A}_{3}$ ' slip has moved forward from the anguloarticular to the dentary. Thus, it may be concluded that muscle $\mathbf{b}$ in loricarioids comprises the two elements identified in other otophysans as $A_{1}$ and $A_{2}$ with the possibility that an inner segment present only in Loricariidae represents $\mathrm{A}_{3}$.

Muscle $\mathbf{c}$ lies dorso-medially to the $\mathrm{A}_{1}, \mathrm{~A}_{2}, \mathrm{~A}_{3}$ complex and at its hyomandibular origin cannot be separated from the outer combined element. Insertion is via a tendon running through connective tissue to the premaxilla. This muscle appears to be the unlabelled dorsal element shown in Alexander's (1965; fig. 17) figure of Hypostomus. This element has probably derived from a dorso-medial separation of the adductor mandibulae. In Astroblepus, the lower portion of muscle $\mathbf{c}$ is not entirely separated from the outer adductor complex (see above, p. $326 \&$ Fig. 13). This condition suggests that muscle $\mathbf{c}$ is a derivative of the medial part of the adductor series which has become attached to the premaxilla via the connective tissue sheet that connects the lower and upper jaws, and the palatine.

Alexander (1965) applied the name retractor premaxillae to the element designated here as muscle d. However, it would seem that Alexander overlooked the fact that part of the adductor mandibulae, here named muscle c, also joins the upper jaw. Concerning functional roles, it would appear that muscle $\mathbf{c}$ performs the action which Alexander ascribed to muscle $\mathbf{d}$, namely being the antagonist of the extensor tentaculi muscles, $\mathbf{e}$ and $\mathbf{f}$, and thus retracting the upper jaw. For this reason I am applying the name retractor premaxillae to the dorsomedial element designated in this text as muscle c.

Muscle d which Alexander (1965) recognised as the 'retractor premaxillae', appears to perform a different function in that, whilst it ultimately inserts into the premaxilla, it is also connected with the lower jaw and with the palatine. In this respect its functional role is not 
at all clear, but manipulation of preserved specimens indicates that a significant downward movement of the palatine occurs when the muscle is pulled posteriorly. Thus, I will refer to it as the retractor palatini. Again, this muscle seems to be a de novo development from the inner part of the adductor mandibulae complex.

In the Diplomystidae, Nematogenyidae and Trichomycteridae, there is no separate medial muscle attaching to the upper jaw. Only in the Astroblepidae are there elements recognisable as homologues of muscles $\mathbf{c}$ and $\mathbf{d}$ in the Loricariidae (p. 326). In most loricariids (e.g. Pterygoplichthys, Fig. 3A) muscle d (retractor palatini) has a plesiomorphic attachment to the underside of the palatine prior to its insertion on the upper jaw. It is hypothesised that phylogenetically the inner part of the adductor mandibulae has, in loricariids, shifted from the lower to the upper jaw via a connection with the palatine.

Muscle a is regarded as the homologue of the retractor tentaculi in other siluroids. Along the lateral border of the muscle runs the ramus maxillaris of the trigeminal nerve which bifurcates anteriorly, one branch innervating the dorsal, and the other the ventral fibres of the muscle. The dorsal face of the muscle is crossed by the buccal ramus which terminates in the maxillary tissue. Similar innervations and nerve course are to be found associated with the retractor tentaculi of other siluroids (see for example Mithel, 1964). The origin of the retractor tentaculi has been the subject of debate (see Winterbottom, 1974), some authors believing the muscle to be derived from $\mathrm{A}_{1}$ and others that it is a de novo development from the medial aspect of the adductor. A more detailed discussion of the matter (Howes, 1983) concludes that the latter is a more likely hypothesis to account for its derivation. The course of the trigeminal nerve rami in Nematogenys and the trichomycterids, taxa lacking a retractor tentaculi, reinforces this view. Both the buccal and maxillary rami lie medial to the principal muscle mass (Fig. 12A). The only way it is possible for the nerves in loricariids to have come to occupy their present position would have been for a muscle segment to have developed ventro-medially to them and for the nerves to have shifted laterally in relation to the muscle.

The most extreme shift of the retractor tentaculi is that in Hypoptopoma and Otocinclus where the lateral ethmoid has extended so far laterally that the muscle makes an angle of about $45^{\circ}$ to the midline.

Muscles $\mathbf{e}$ and $\mathbf{f}$ are homologous with the extensor tentaculi of other siluroids. Both sections are derivatives of the adductor arcus palatini and form the antagonists of the retractor tentaculi (see Winterbottom, 1974: 240). In Astroblepus, the extensor tentaculi is of a primitive, single element whose fibres run laterally from the lateral ethmoid and insert on the posterior portion of the palatine (Fig. 13B). The muscle is floored by a thick tendinous sheet connecting the parasphenoid with the lateral ethmoid processes.

Opercular muscle morphology in loricariids is correlated with the size and position of the opercular bones. In the majority of taxa the operculum is small, with its dorso-posterior border sealed to the pectoral girdle by a membrane, leaving only a ventral opening. Such immobility of the operculum has, in some taxa, led to atrophy or disappearance of the levator and adductor operculi muscles (see above, p. 322). Although the dilatator operculi is sometimes, as in Pseudohemiodon, markedly reduced, it is always present and in Ancistrus it extends from the dorsal midline of the cranium and cranial roofing bones. In some taxa the dilatator operculi originates from the hyomandibula rather than the cranium. The hyomandibula is firmly and immovably articulated with the cranium, dorsally via an interdigitation with the prootic, and posteriorly with the pterotic-posttemporal plate; the loss of hyomandibular cranial fossae is synapomorphic for loricariid taxa. The sites of origin of the levator and adductor operculi muscles are similar to those in other siluroids, although somewhat modified owing to the ventral extension of the pterotic-posttemporal plate. What appears to be the adductor operculi in one group of loricardiids (e.g. Panaque, Pseudacanthicus; $\mathrm{p}$. 321 ) has shifted its point of insertion from the operculum to the preoperculum.

The opercular muscles in Astroblepus (Astroblepidae) have a relatively plesiomorphic arrangement. The dilatator operculi is strongly developed and runs postero-ventrally from the pterotic to its insertion on the antero-dorsal part of the operculum. Levator and adductor 
operculi muscles also originate from the pterotic and insert on the dorso-medial surface of the operculum.

The levator arcus palatini is a stout muscle originating from the pterotic and sphenotic, and inserting on the hyomandibula.

In Nematogenys (Nematogenyidae) the opercular muscles are complex, the dilatator operculi is large and plesiomorphic in its angle of insertion, i.e. postero-ventral, cf. the antero-ventral, apomorphic angle, in Loricariidae. The levator operculi inserts on the lateral face of the operculum; the adductor operculi is in its more usual position of the medial face. The levator arcus palatini is a large element with its lateral fibres interdigitating with the antero-ventral fibres of the dilator operculi.

In the Trichomycteridae the dilatator operculi is hypertrophied and is separable into lateral and medial parts. It originates from the underside of the frontal to pass beneath a sphenotic bridge where its lateral profile becomes convex before inserting on the lateral side of the long dorsally directed opercular process. The strap-like medial part of the muscle joins the medio-distal area of this process. The ventral portion of the dilatator operculi joins an aponeurosis with the dorso-posterior part of a muscle extending along the lateral face of the preoperculum. This muscle may be either a disassociated part of the adductor complex, or yet another segment of the dilatator operculi which has shifted ventrad.

The levator and adductor operculi also are hypertrophied and insert on the dorso-lateral and medial margins of the operculum respectively. The hypertrophy and lateral insertion of the dilatator operculi in the Nematogenyidae and the Trichomycteridae is viewed as synapomorphic - such a condition is unknown elsewhere in siluroids.

\section{Interrelationships of loricariids based on myological characters}

Although of restricted taxonomic range in terms of numbers of 'genera' examined (but, see below, p. 338), the anatomical data obtained from this investigation suffice to hypothesise phylogenetic relationships for the groups of loricariid genera. The scheme is based on what are considered to be derived states of jaw and opercular muscle characters. Two myological synapomorphies unite the Loricariidae and Astroblepidae as a monophyletic lineage; these are:

1. Presence of a medial muscle stemming from the suspensorium and inserting on the upper jaw (premaxilla). The muscle is recognized as a retractor premaxillae (p. 327).

2. Complete medial separation of the protractor hyoideus (p. 319). Within this lineage, the astroblepids retain a more generalized cranial muscle pattern and are considered to represent the plesiomorphic sister group to the loricariids. The loricariidae are defined myologically by the presence of a further medial adductor element inserting on the palatine (retractor palatini; p. 327) and by the orientation of the dilatator operculi which is angled anteroventrally rather than postero-ventrally as in other siluroids and, indeed, other teleosts.

Within the Loricariidae, the following sequences of derived states in jaw and opercular muscles are discernible and are represented as a cladogram in Fig. 14.

1. Dilatator operculi angled antero-ventrally; retractor palatini present: LORICARIIDAE.

2. Reduction of opercular muscles and levator arcus palatini.

3. Lateral shift of retractor tentaculi: Hypoptopoma, Otocinclus.

4. Expansion of retractor tentaculi: Chaetostoma, Lipopterichthys, Hemipsilichthys.

5. Retractor palatini muscles meet in midline: Loricaria (part), Farlowella, Sturisoma.

6. Loss of levator arcus palatini: Loricaria (part).

7. Ventral division of retractor tentaculi inserts on palatine: Loricaria (part).

8. Loss of levator and adductor operculi: Pseudohemiodon, Hemiodonichthys.

9. Dilatator operculi originating from cranial roof, levator operculi from complex vertebrae: Ancistrus, Lithoxus. 
10. Anterior shift of dilatator operculi; adductor operculi spans posttemporal-pterotic plate and preoperculum: Panaque, Cochliodon, Stoniella, Pseudancistrus, Pseudacanthicus, Acanthicus.

Because it is based on a single character complex, this synapomorphy scheme has limited information content and, for the most part, is a series of unresolved polychotomies. In order to test, and more fully resolve the scheme, various osteological characters have been utilised.

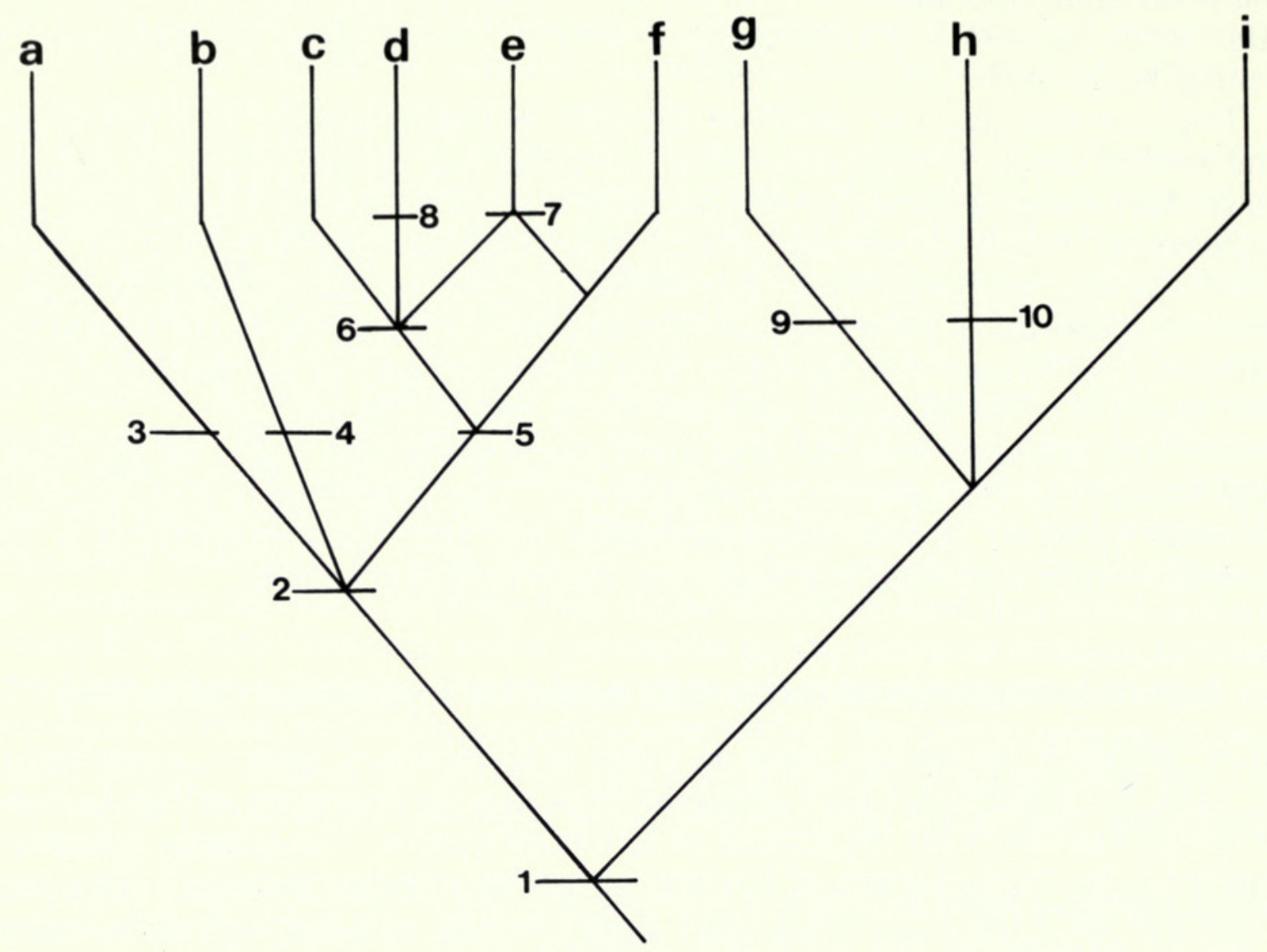

Fig. 14 Cladogram of loricariid taxa based on jaw and opercular muscle synapomorphies (see text, p. 329). $\mathrm{a}=$ Hypoptopoma, Otocinclus; $\mathrm{b}=$ Chaetostoma, Lipopterichthys, Hemipsilichthys; $\mathrm{c}=$ Loricaria (part); d=Pseudohemiodon, Hemiodonichthys, Crossoloricaria; $\mathrm{e}=$ Loricaria (part); $\mathrm{f}=$ Farlowella, Sturisoma $; \mathrm{g}=$ Ancistrus, Lithoxus; $\mathrm{h}=$ Pseudacanthicus group $; \mathrm{i}=$ Hypoptostomus, Neoplecostomus. Pterygoplichthys.

\section{Congruent osteological features in Loricariidae}

Four osteological characters are analysed. Three that are functionally integrated with the facial and opercular muscles, and one that has no direct relationship with the cranial musculature. They are: the lateral ethmoid; pterygoid channel; opercular bones and the lateropterygium of the pelvic girdle.

\section{Lateral ethmoid and nasal capsule}

Alexander (1965) noted that in most siluroids the nasal cavities are bounded medially by the ethmoid and posteriorly by the lateral ethmoid. In the majority of siluroids the palatine lies adjacent to the mesethmoid and contributes no part to the nasal cavity. In Nematogenys, (Nematogenyidae) the palatine is large and widely separated from the mesethmoid, forming an angle between the lateral ethmoid and the maxilla. The nasal cavity is thus bounded laterally by the palatine (Fig. 15B). 


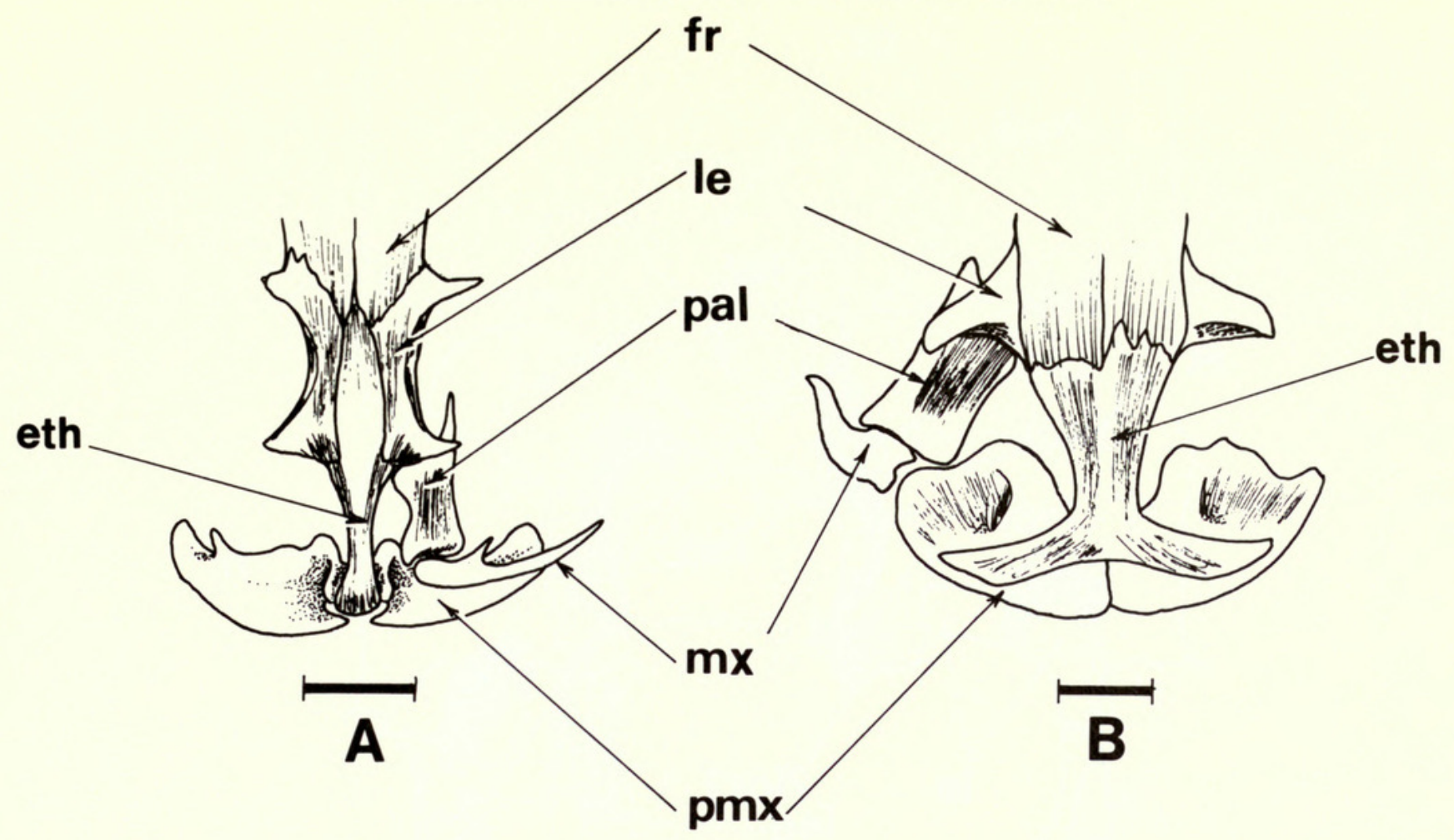

Fig. 15 Neurocrania, dorsal view of anterior region and upper jaw bones of A, Astroblepus festae $(\mathrm{BMNH}$ 1864.11.4:18); B, Nematogenys inermis $(\mathrm{BMNH} 1883.11 .27: 49)$. Scales $=5 \mathrm{~mm}$. eth= ethmoid; $\mathrm{fr}=$ frontal; le $=$ lateral ethmoid; $\mathrm{mx}=$ maxilla; $\mathrm{pmx}=$ premaxilla; $\mathrm{pal}=$ palatine.

Synapomorphic for Astroblepus (Astroblepidae) species is an expanded palatine which occupies the area between the lateral ethmoid and the mesethmoid. Its dorsal surface is excavated and accommodates the entire nasal capsule (Fig. 15A). Elsewhere this feature occurs only in Trichomycterus rivulatus (Trichomycteridae). If it is regarded as synapomorphic with that of Astroblepus, then the monophyly of Trichomycterus is in doubt.

In the Loricariidae the nasal capsule is contained within the lateral ethmoid. Entire encapsulation within the lateral ethmoid occurs also in the Callichthyidae (see Alexander, 1965). In some species of Doradidae and Auchenipteridae the posterior part of the nasal cavity is housed within the bone. Two conditions of encapsulation occur in loricariids; one in which the nasal cavity is incompletely walled and the other where the cavity is entire.

The former is exemplified by Hypoptopoma where the nasal cavity, whilst being entirely within the lateral ethmoid opens anteriorly as a shelf adjacent to the mesethmoid (Fig. 16A). The anterior border of the lateral ethmoid shelf meets the posterior border of the palatine. A similar situation occurs in Sturisoma, Pterygoplichthys, Chaetostoma (Fig. 18B), Hemipsilichthys and Pseudacanthicus. However, in all these taxa the anterior opening of the nasal cavity is partially occluded by a medially directed process extending from the lateral wall of the cavity (Fig. 16B). In Ancistrus the cavity is entire although a medially directed process protruding from its lateral wall is discernible (Fig. 17). The nasal cavity is entire in Loricaria, Farlowella (Fig. 18A) and Neoplecostomus.

The width of the anterior rim of the cavity is variable, being narrow in Farlowella and long and shelf-like in Ancistrus (Figs 17 and 18A). The length of the pre-nasal cavity part of the lateral ethmoid seems not to be coordinate with any elongation of the mesethmoid. Indeed, topographical relationship between the nasal cavity and its surrounding elements is maintained. In those taxa where there is mesethmoidal elongation, Farlowella and Sturisoma, there is no corresponding proportional lengthening of the lateral ethmoid. The lateral ethmoid serves as the site of origin for the retractor tentaculi muscle and it is likely that extension of the bone's surface area corresponds with hypertrophy of the muscle, as in Chaetostoma. 


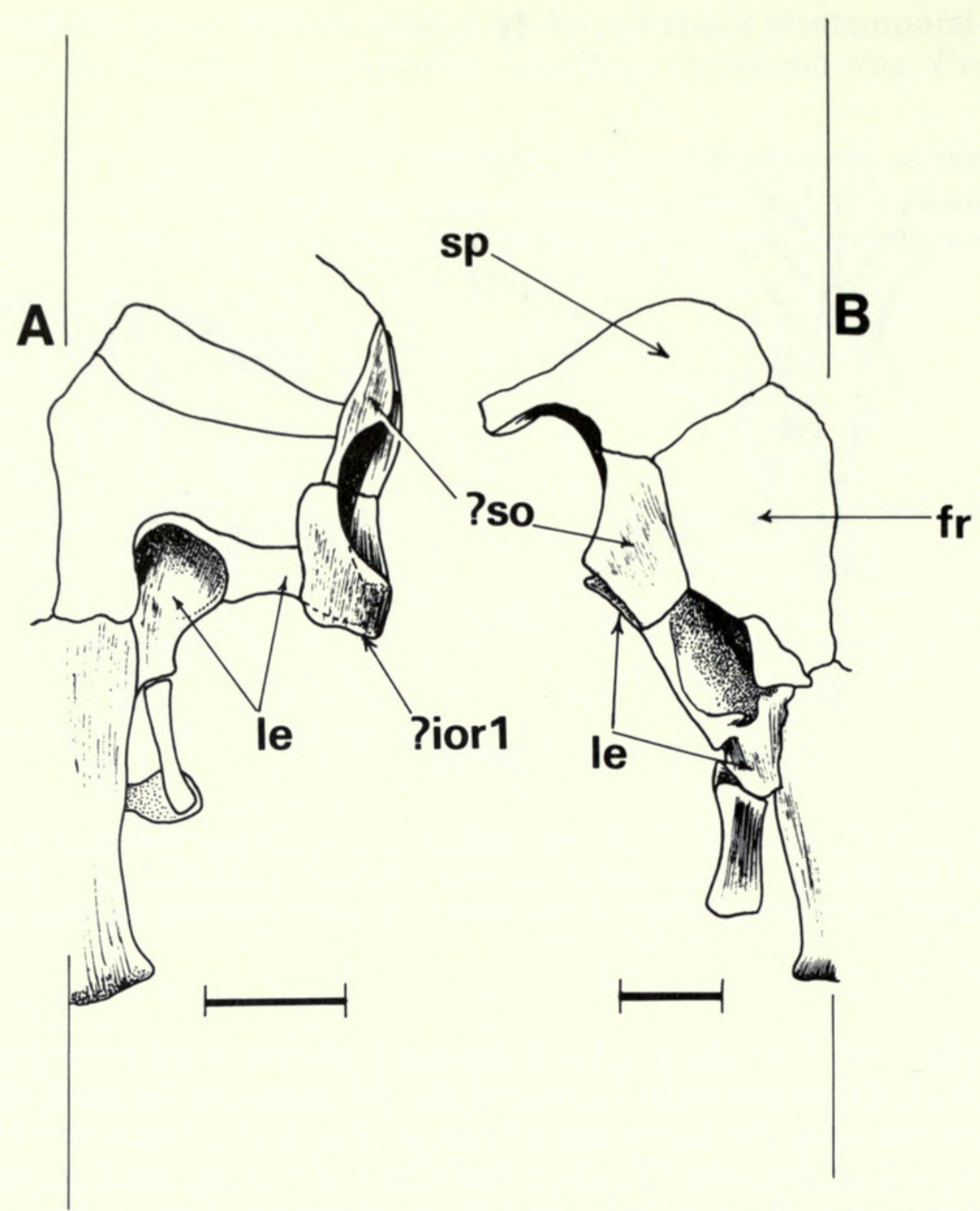

Fig. 16 Neurocrania, dorsal view of anterior and orbital regions of A, Hypoptopoma carinatum (uncat.); B, Pterygoplichthys multiradiatus $(\mathrm{BMNH}$ 1897.12.1:280). io =infraorbital; so=possible supraorbital. Scale $=5 \mathrm{~mm}$.

In Hypoptopoma and Otocinclus the lateral ethmoid margin is extended laterally with the consequence that the retractor tentaculi muscle is also shifted laterally with respect to the other adductor muscles. Unlike other loricariids, the eyes in these genera are entirely lateral. It may be mentioned here that Gosline (1947) appears to have confused epidermal plates with neurocranial elements. His figures of the skull of Hypoptopoma show a 'dermosphenotic' lying lateral to the nasal cavity, i.e. forming the anterior border of the true neurocranium. In fact Gosline's 'dermosphenotic' is the lateral ethmoid, and the unlabelled bone shown lateral to it is perhaps the 1st infraorbital (Fig. 16A). It is also pertinent to draw attention to a dermal bone in some loricariids lying in the position of a supraorbital. One defining character of siluroid fishes is that they lack a supraorbital; see Fink \& Fink, 1981.

A naive hypothesis to account for the position of the nasal cavity in the lateral ethmoid would be to assume, during phylogeny, a posterior migration of the nasal organ from its plesiomorphic position, adjacent to the anterior mesethmoid, via an anterior lateral ethmoid bridge. There is no extant 'transitional series' to indicate that this was the phylogenetic history of the nasal cavity shift. On the contrary, development of an anterior extension to the lateral ethmoid appears to be an apomorphic feature connected with the retractor tentaculi muscle, rather than indicating a plesiomorphic retention of the pathway along which the nasal organ shifted. Indeed, in assumed plesiomorphic members of the Loricariidae, e.g. Neoplecostomus, the nasal cavity is entirely enclosed within the lateral ethmoid. 


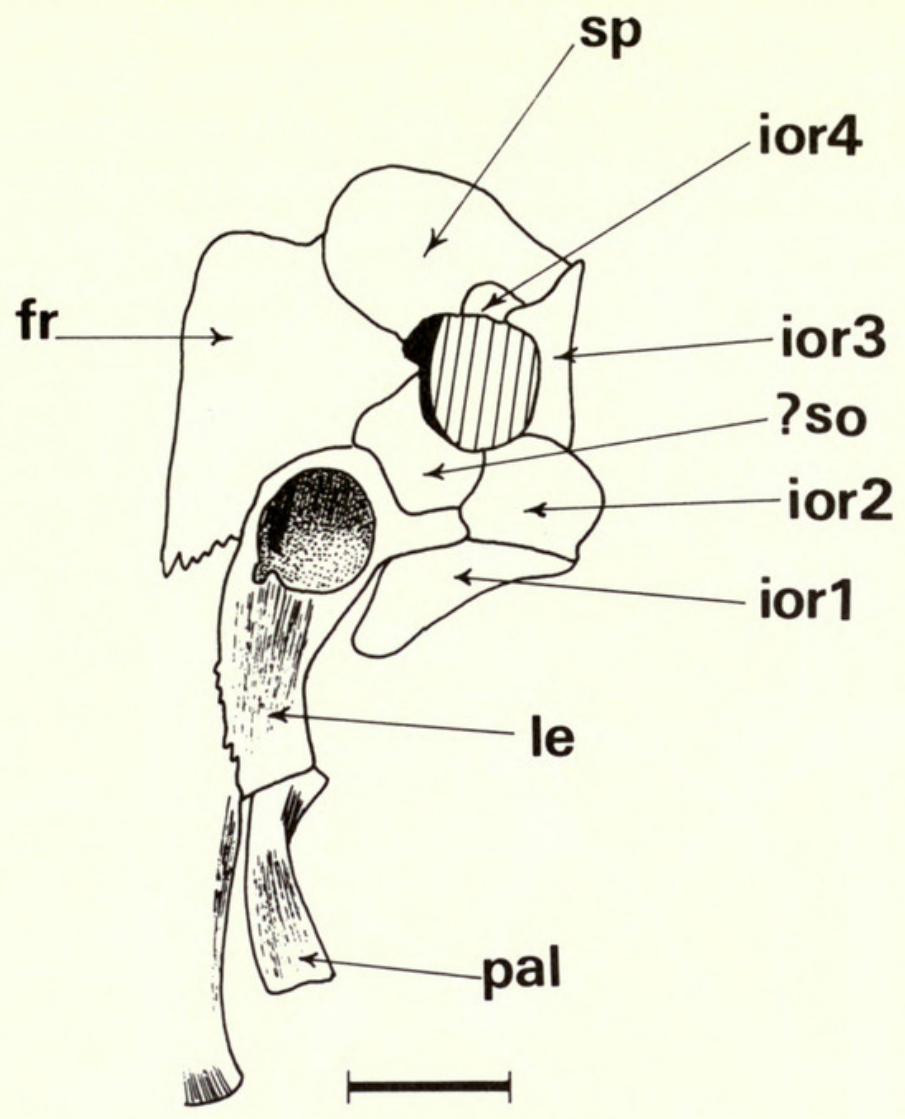

Fig. 17 Neurocranium dorsal view of anterior and orbital regions of Ancistrus stigmaticus (BMNH 1901.5.8:10). Scale $=5 \mathrm{~mm}$. Abbreviations as in previous captions.

In Astroblepus the lateral ethmoid has a plesiomorph otophysan morphology i.e. short, and triangular; see Fink \& Fink, 1981; Howes, 1981. The morphology and position of the palatine is, however, derived and might be viewed as the precursory condition of nasal organ reorientation in loricariids. This hypothesis is refuted, however, by the essentially plesiomorphic rod-shaped morphology of the palatine in the Loricariidae.

In the Callichthyidae the nasal organ is also enclosed within a cavity in the lateral ethmoid. Unlike the loricariids, the nasal cavity is well-separated from the mesethmoid, which is short and triangular, regarded as plesiomorphic in otophysans; see Fink \& Fink, 1981; Howes, 1981. A superficial investigation of callichthyid osteology indicates that the lateral ethmoid encapsulation of the nasal organ has been derived independently from that in loricariids. More detailed studies of callichthyid and loricariid osteology are necessary before the feature can be accepted as a synapomorphy.

\section{Pterygoid channel}

In the Loricariidae the extensor tentaculi muscles originate from the lateral face of the pterygoid. The term 'metapterygoid' is avoided here as the elements of the siluroid suspensorium appear to have been misinterpreted by several authors (see Howes, 1983). The pterygoid in loricariids contacts the lateral ethmoid along its anterior length. In some taxa there is a pterygoid ridge or channel and it is the medial face of this ridge that provides the site of origin for the outer extensor tentaculi muscle, muscle $\mathbf{e}$ in the above text. In its more derived state, the pterygoid ridge extends dorsally to contact the lateral ethmoid and so completely encloses the extensor tentaculi in a tunnel.

A pterygoid ridge is weakly developed in Pseudacanthicus, Stoniella and Acanthicus; welldeveloped in Pseudancistrus, Hemipsilichthys, Lipopterichthys and Chaetostoma, and tunnel-like in Ancistrus, Pterygoplichthys, Panaque and Farlowella. In Hypostomus and Cochliodon, the anterior and posterior parts of the ridge are produced dorsally, with con- 


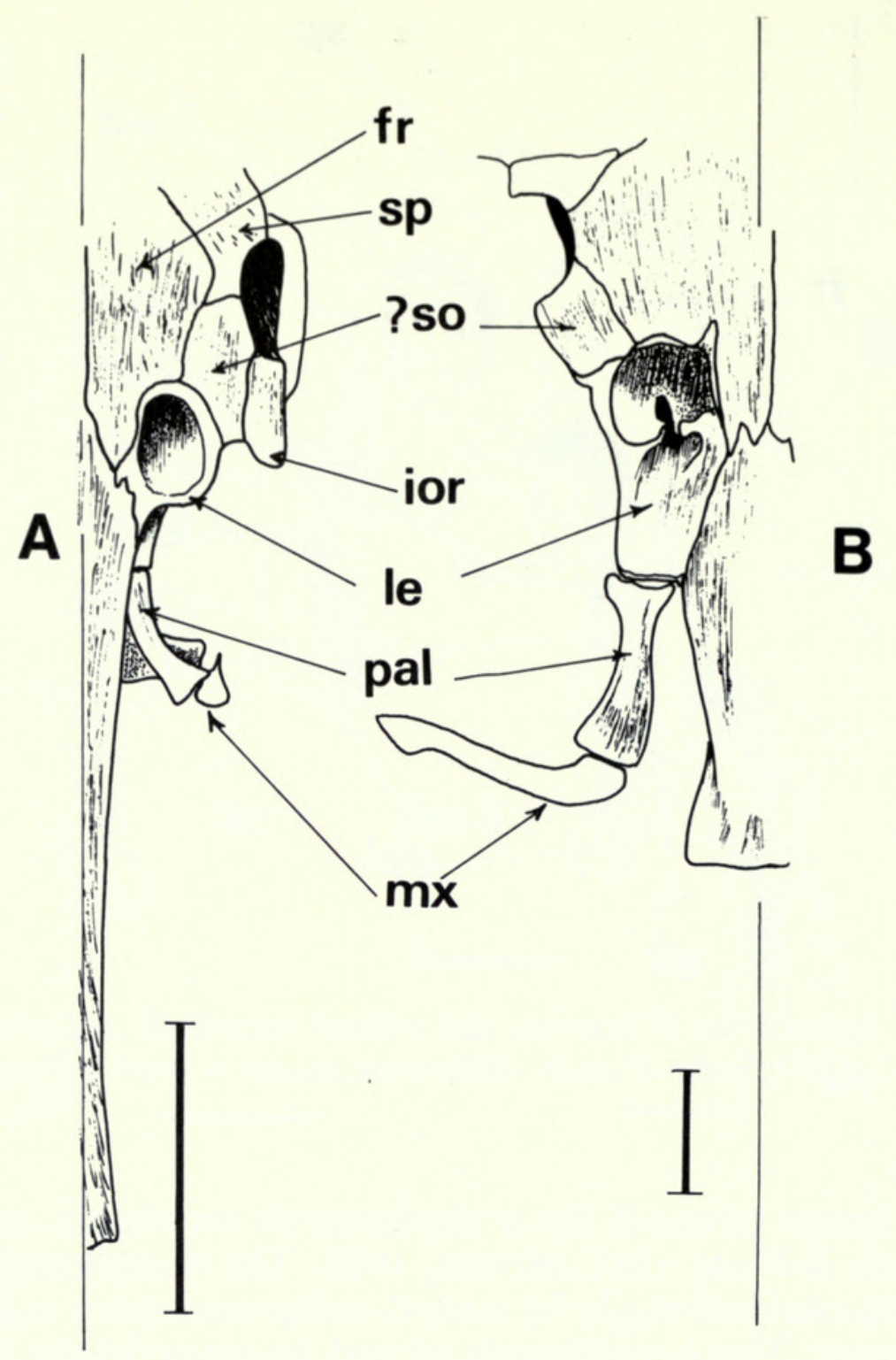

Fig. 18 Neurocrania, dorsal view of anterior and orbital regions of A, Farlowella knerii (BMNH 1880.12.5: 206); B, Chaetostoma anomalus (BMNH 1903.6.30:102). Scales $=5 \mathrm{~mm}$. Abbreviations as previous captions.

nective tissue covering the intervening concavity. No development of the ridge is evident in Hypoptopoma, Otocinclus, Loricaria, Sturisoma, Pseudohemiodon and Neoplecostomus.

In the Astroblepidae and Nematogenyidae, the pterygoid is extensive, and in astroblepids its posterior margin, the 'metapterygoid' is sutured with the hyomandibula, as it is in loricariids. There is no lateral pterygoid ridge present in either family.

The pterygoid channel character states are incongruent with the cladogram of muscle characters. If the presence of a pterygoid ridge-tunnel is accepted as a synapomorphy, then that lineage containing Chaetostoma and Hemipsilichthys must be closely united with that represented by Hypostomus. So too, must Farlowella be united with Ancistrus. These seem unlikely combinations in the light of other synapomorphies (p. 338) and the most parsimonious explanation is to accept the pterygoid channel as having been derived independently in several lineages.

\section{The opercular series}

Some loricariid genera possess a mechanism whereby the spine-bearing 'interoperculum' can be rotated outward and the spines produced horizontally. Gosline (1947) was unable to find an interoperculum in Ancistrus and was of the opinion that what had been referred to as that bone was a patch of dermal plates. Gosline was only partially correct. He is certainly right that in Ancistrus the spine-bearing element does not appear to be the interoperculum 
but a partially ossified ligament. None the less, this ligament actually connects the operculum with the interoperculum which is immovably sutured to the preoperculum. A similar situation is present in Pseudacanthicus (Fig. 19B).

In Chaetostoma the situation is quite different. Here, the interoperculum is completely movable and articulates with the condyle of the opercular ventral extension (Fig. 19A). It is ligamentously attached to the preoperculum. In all taxa with a spine-erecting mechanism the operculum is elongate with an antero-ventral extension. There are, however, marked

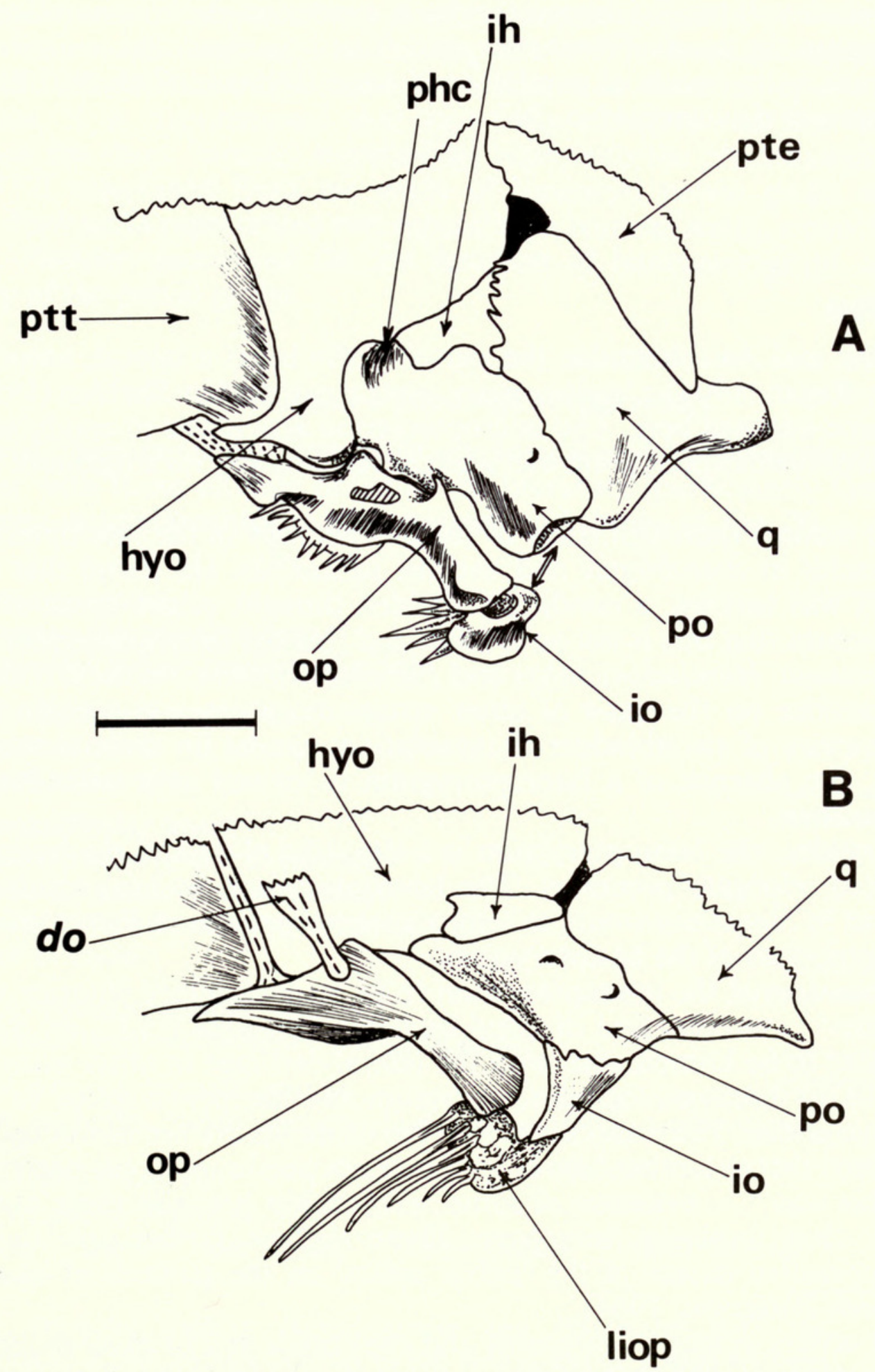

Fig. 19 Pterygoid and opercular bones in medial views of A, Chaetostoma anomalus, B, Pseudacanthicus serratus. The hatched portion of the operculum in A indicates the insertion area of the dilatator operculi muscle. hyo=hyomandibula; ih=interhyal; io=interoperculum; liop= interopercular-opercular ligament; op=operculum; phc=pterygoid cavity for interhyal; $\mathrm{po}=$ preoperculum; $\mathrm{pte}=$ pterygoid $; \mathrm{ptt}=$ posttemporal-pterotic plate; $\mathrm{q}=$ quadrate . 
differences in morphology distinguishing two groups of taxa. In Pseudacanthicus, Ancistrus and Lithoxus there is a single articulation of the operculum with the hyomandibula at the point of the dilatator operculi muscle insertion. In Chaetostoma and Lasiancistrus there is a double articulation, one with the hyomandibular condyle and the other, via a dorsal process, with the medial surface of the preoperculum (Fig. 19A). These two groups of taxa also differ in the topographical arrangement of the suspensorial bones (cf. Figs. 19A \& B). From these observations it is suggested that the 'interopercular' spine-erecting mechanism has been derived independently in two lineages of loricariids.

In some Trichomycteridae there is also an antero-ventral process of the operculum which articulates with a socket on the medial face of the spine-bearing interoperculum, e.g. Branchioica, Pareiodon. If the Trichomycteridae is a monophyletic assemblage (see remarks on p. 331 concerning the genus Trichomycterus) then it is clear that a similar mechanism to that of loricariids is the result of parallelism (sènsu Holmes, 1980: 49). The function of interopercular spines is discussed on p. 343.

\section{The lateropterygium}

In the Loricariidae and Astroblepidae the pelvic girdle bears a lateral, anteriorly directed process named by Regan (1904) a 'rudimentary ventral ray' and by Shelden (1937) a 'lateropterygium', the name adopted here. The lateropterygium articulates in condylar fashion with the lateral process of the basipterygium and is anchored laterally via a ligament to an adjacent body scute.

Shelden (1937) made a thorough study of the morphology of the lateropterygium as well as the pelvic muscles in Astroblepus and various loricariids. He found that in Farlowella a lateropterygium was lacking, a condition Shelden thought might be an artefact of preparation. I can confirm that this is not an artefact and that the lateropterygium is absent also in Loricaria, Sturisoma, Hemiodonichthys and Pseudohemiodon. As these taxa are admitted within the Loricariidae on the basis of other synapomorphies, e.g. specific form of scute development; structure of swimbladder encapsulation; caudal fin skeletal morphology and jaw musculature, the absence of a lateropterygium is viewed as a secondary loss in this lineage, = Loricariinae.

In the Astroblepidae, the lateropterygium is a disc-like plate and the basipterygium has posteriorly directed, elongate processes. The lateropterygium in Loricariidae varies from short and broad, as in Neoplecostomus, to long and rod-shaped as in Pterygoplichthys. There are no posterior processes of the basipterygium.

Regan (1904) considered the lateropterygium to be a rudimentary anterior ventral fin ray which had become '... internal and directed forwards'. Shelden (1937) on the other hand, thought the element to be homologous with the lateral cartilage in other siluroids.

Arratia et al. (1978) discussed the lateropterygium and the 'pelvic splint' in Nematogenys and the Trichomycteridae. They concluded that the elements are not homologous. However, they then considered that as neither lateropterygium nor pelvic splint has been recorded from other siluroids this was '... evidence of some relationship between these groups of South American fishes', thus implying homology. These authors further confuse the issue by referring to the primitive nature of the 'pelvic splint' on the grounds of its occurrence in 'lower' teleosts (vide Patterson, 1964).

A pelvic splint occurs in many characoids and cyprinoids and from its shape and position appears to be homologous with that similar element in other teleosts (Patterson, 1964: 444). Among siluroids a supplementary pelvic element is recorded only in the Trichomycteridae, Astroblepidae, Nematogenyidae, Loricariidae and Diplomystidae. In the Trichomycteridae the morphology of the bone is similar to that in other otophysans except that it is associated with the pelvic musculature and is detached from the first pelvic ray (see Arratia et al., 1978). 
Within the Loricariidae, the lateropterygium appears in its simplest form in the Hypoptopominae where in Otocinclus it resembles the pelvic splint of trichomycterids and diplomystids but, unlike the conditions in those taxa, it is orientated antero-dorsally instead of latero-posteriorly. This condition suggests that the lateropterygium is a pelvic splint which has become reorientated and articulated with the pelvic bone (as suggested by Regan, 1904; see above). Thus, the lateropterygium would be the homologue of the pelvic splint (rudimentary spine) in other teleosts, but its peculiar nature and articulation with the pelvic bone is a derived condition limited to the Loricariidae and Astroblepidae only.

Gosline (1974) was of the opinion that the lateropterygium was not a 'good classifying character, and that its presence, size and shape depend more or less on the extent of the plating of the sides and abdomen'. There must, as Gosline suggests, be a correlation between body shape, scute morphology and the development of the lateropterygium. Nevertheless, the presence and similarities of the bone in various taxa must indicate a shared ancestral condition. Thus, it is hypothesised that especially elongate rod-like lateropterygia are derived, whereas the short, broader morphology represents the plesiomorph condition.

Shelden (1937) concluded from his study of loricariid pelvic girdle morphology that Ancistrus and Farlowella represented two separately advanced states, a conclusion supported by this study. Shelden accounted for the function of lateropterygium as increasing the manoevrability of the pelvic girdle.

\section{Myological + osteological characters}

Utilizing derived character states from both myological and osteological complexes detailed above, together with those already noted in the literature (particularly Gosline, 1947), the following scheme of relationships is hypothesized and shown in Fig. 20.

1. Lateropterygium present

2. Retractor premaxillae muscle present

3. Protractor hyoideus muscle medially divided

Astroblepidae

4. Nasal capsule confined to palatine

5. Gill-rakers absent

6. Lateropterygium disc-like

7. Lack of hyomandibulae fossae

8. Nasal capsule confined to lateral ethmoid

9. Dilatator operculi muscle antero-ventrally orientated; retractor palatini muscle present

10. Body encased in scutes

11. Reduction of opercular muscles, dilatator operculi confined to hyomandibula (Neoplecostomus)

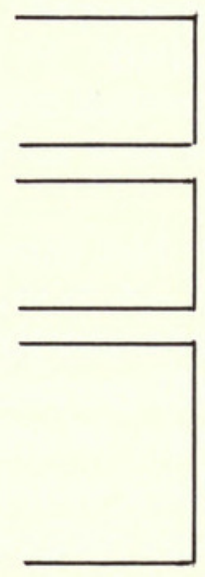

Loricariidae

Astroblepidae

Loricariidae

12. Expansion of retractor tentaculi muscle

13. Reduction of posterior cranial elements (e.g. supraoccipital, posttemporalpterotic plate)

14. Jaws lengthened and widened

15. Lateral cheek spines (Hemipsilichthys)

16. Interopercular spine mechanism Lipopterichthys

(Chaetostoma, Lasiancistrus,

17. The single character uniting Hypoptopoma and Otocinclus with the loricariine genera is the midline contact of the ventro-lateral scutes between the anus and anal fin origin (Gosline, 1947: 96) versus a single, azygous preanal plate in other loricariids. Synapomorphic for this lineage is the lateral position of the retractor tentaculi. On the basis of the characters used, it is not possible at this point to resolve a trichotomy of the neoplecostominechaetostomine-hypoptopomine (loricariine) lineages. 
18. Retractor palatini muscles meet in the midline

19. Caudal peduncle depressed, caudal vertebrae elongated, lateral scutes reduced.

20. Lateropterygium lost.

21. 'Adipose' fin lost; reduction of caudal fin ray number (10-14). These characters are of dubious value; the 'adipose' fin is also absent in some neoplecostomines, but it is noted here because of its complete absence in all loricariine taxa; the caudal fin ray number may be reduced in other lineages but appears consistently so in loricariines.

22. Mesethmoid elongated (Sturisoma + Farlowella)

23. Extensor tentaculi muscle enclosed in pterygoid tunnel (Farlowella+ Loricaria platystoma); tendon of retractor ischii muscle runs through bodyarmour canals (Farlowella; see Shelden, 1937: 63).

24. Palatine lamellate, usually convex; $3 \mathrm{rd}, 4$ th and often 5 th ceratobranchials expanded (?all taxa)

25. Ventral part of retractor tentaculi inserts on palatine (Loricaria, part)

26. Postorbital notch

27. Jaw teeth reduced or absent (Loricaria, part)

28. Palatine laterally compressed, extensor tentaculi inserts on its midventral border; papillae developed over pterygoid. (Pseudohemiodon, Hemiodonichthys)

29. Lower pharyngeal bones edentulous (?all taxa; see Gosline, 1947: 86)

30. Lateropterygium well-developed

31. Pterygoid channel or tunnel (Hypostomus, Pterygoplichthys, Cochliodon)

32. Pseudointeropercular mechanism entirely or partially developed (Peckoltia, Hemiancistrus)

33. Anterior shift dilatator operculi medial to orbit, adductor operculi bridges posttemporal-pterotic plate and preoperculum; upper jaw reduced, premaxillae coalesced (Panaque, Stoniella, Pseudacanthicus, Acanthicus, Pseudancistrus)

34. Dilatator operculi originates from cranial roof, levator operculi from complex vertebrae; levator arcus palatini joins tendon of dilatator operculi. (Ancistrus, Lithoxus)

The cladogram constructed from nested sets of myological and osteological characters is, for the most part, congruent with that constructed from myological characters alone. It will be necessary to utilize other character sets, particularly those involving the morphology of the gill-arches, swimbladder encapsulation and the pectoral girdle in order to more highly corroborate this proposed phylogeny.

\section{Classification of Loricariidae}

The most recent synopsis of the Loricariidae is that of Isbrücker (1980) wherein are recognized six subfamilies, the Neoplecostominae, Lithogeneinae, Hypostominae, Ancistrinae, Hypoptopominae and Loricariinae. The genera included in these subfamilies follows, for the most part, those of Gosline (1947), Isbrücker, however, retains Regan's (1904) concept of the Neoplecostominae as monotypic by referring to it only Neoplecostomus, whereas Gosline has included 12 genera in the subfamily. Few representatives of those genera recognised by Gosline have been available for my study and their placement in one or other of the subfamilies recognised here is open to question. I have recognised Neoplecostomus as a sole representative of the Neoplecostominae purely on its retention of plesiomorph characters.

In the cladistic scheme presented in Fig. 20 the major lineages are equivalent to subfamilies and the included taxa are broadly those currently contained in the Hypostominae, Hypoptopominae and Loricariinae. Genera formerly incorporated in the Ancistrinae are here divided between the Hypostominae and Chaetostominae $=$ Chaetostomidi, Fowler, 1958. No speci- 


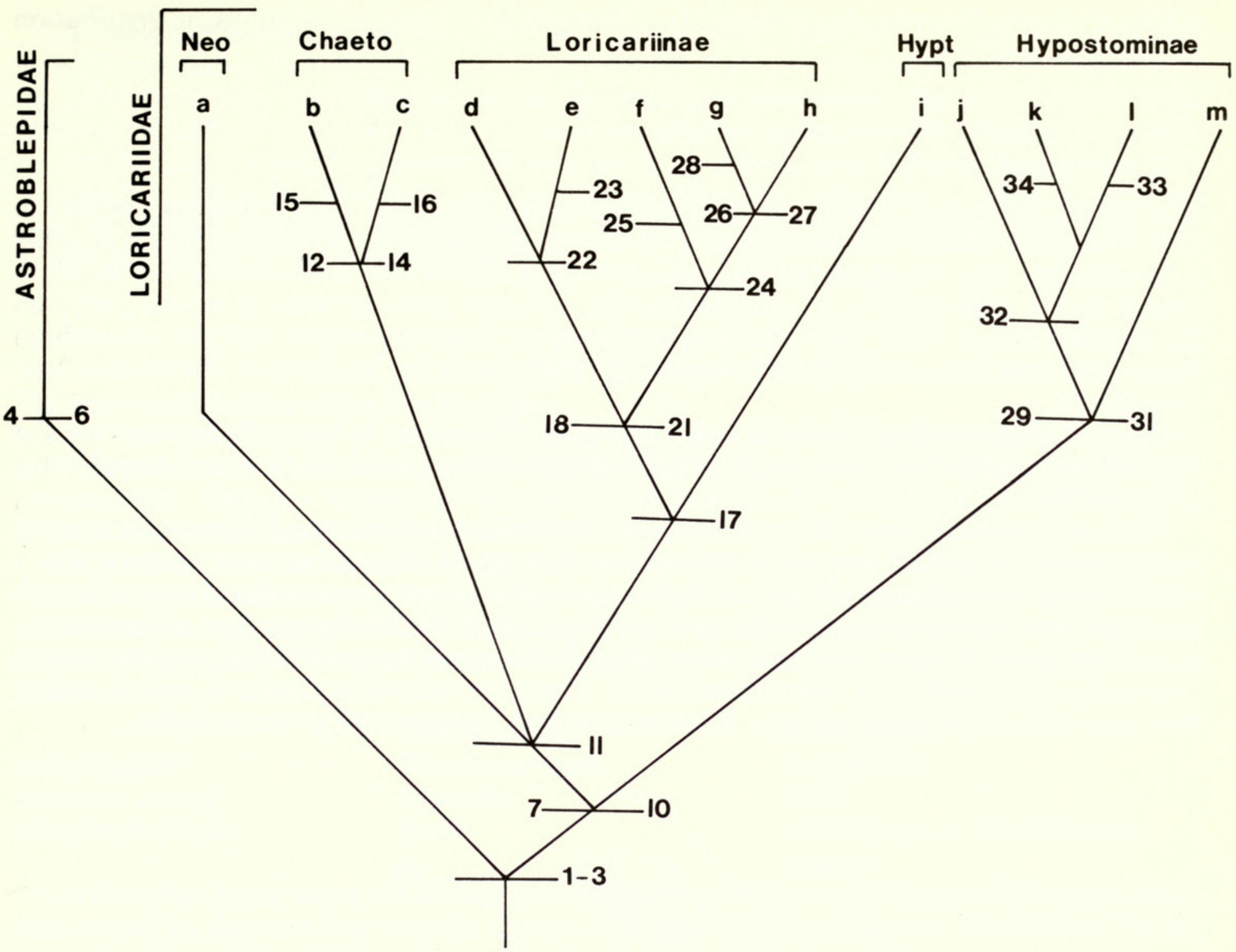

Fig. 20 Cladogram of the Astroblepidae and Loricariidae based on muscle and skeletal synapomorphies (see text, p. 337). $\mathrm{a}=$ Neoplecostomus $(\mathrm{Neo}=$ Neoplecostominae); $\mathrm{b}=$ Hemipsilichthys, $c=$ Chaetostoma,$\quad$ Lasiancistrus, Lipopterichthys, $\quad($ Chaeto $=$ Chaetostominae $) ; \quad \mathrm{d}=$ Sturisoma; $\mathrm{e}=$ Farlowella $; \mathrm{f}=$ Loricaria (part, strigilata, simillima), Metaloricaria $; \mathrm{g}=$ Pseudohemiodon, Hemiodonichthys, Crossoloricaria; $\mathrm{h}=$ Loricaria (part, e.g. cataphracta); $\mathrm{i}=$ Hypoptopoma, Octocinclus, Parotocinclus, ?Microlepidogaster, $($ Hypt $=$ Hypoptopominae $) ; \mathrm{j}=$ Pekoltia, Hemiancistrus; $\mathrm{k}=$ Ancistrus, Lithoxus; $1=$ Panaque, Stoniella, Pseudacanthicus, Acanthicus, Pseudancistrus; $\mathrm{m}=$ Hypostomus, Pterygoplichthys, Cochliodon.

mens of Lithogenes have been examined and thus no comment can be made concerning the status of the monotypic subfamily Lithogeneinae.

Isbrücker (1980) lists 70 loricariid genera; it is likely that many are synonyms, particularly those recognised on the basis of single specimens. It is pertinent to note that of the 70 genera, 21 are monotypic and so might merely reflect the generic concepts of their respective authors. The characters used to define many loricariid genera appear to depend on meristic and dental differences, varying numbers of body scutes and lower lip morphology. Most of these characters appear to be gradal. A character that appears to be significant in the classification of Loricaria species is the presence in some of a posterior orbital notch or fossa. The fossa is variously developed, varying from a slight indentation to a deep, medially directed channel. There is no organ or vessel contained within the fossa and it is floored with connective tissue. Its function is unknown but may serve to enlarge the posterior visual field. Presence of a post-orbital fossa is regarded as synapomorphic for those Loricaria species in 
which it occurs. In a sample of 16 species belonging to 7 'genera' the following distribution of the fossa is recorded:

Absent: Crossoloricaria, Spatuloricaria, Loricaria, Loricariichthys

Slightly developed: Paraloricaria, Loricaria, Ricola

Well developed: Rineloricaria, Loricaria, Loricariichthys

One genus, Loricaria, appears in all three morpho-groups and Loricariichthys appears in two. This result indicates that the present generic classification of the Loricariinae is possibly a paraphyletic one. In support of this statement I find that in Loricaria sensu stricto as represented by the type species, L. cataphracta, the retractor tentaculi muscle inserts partly on the palatine (see p. 315). This feature is restricted to those taxa which lack the post-orbital fossa, or at best have it slightly developed, e.g. 'Limatulichthys' punctatus; 'Pseudoloricaria' laeviuscula.

Other characters which override current generic allocations of loricariine species are the ligamentous suspension of the upper jaw, the length of the lateral ethmoid and morphology of the palatine.

There are two basic types of ligamentous jaw suspension in Loricaria, (1) where the maxilla is attached to a ventral process of the vomer via a single, folded ligament; there is also a small rostral cartilage, and (2) where there are several ligaments connecting the maxilla with the vomer and there is a large rostral cartilage (Figs 21A \& B). The former type of jaw suspension is present in Loricaria labialis, assigned by Isbrücker to Loricariichthys, L. cataphracta, Sturisoma, Farlowella and Hemiodonichthys. The latter occurs in Loricaria jubata and $L$. brunneus which Isbrücker refers to Rineloricaria and Loricariichthys respectively.

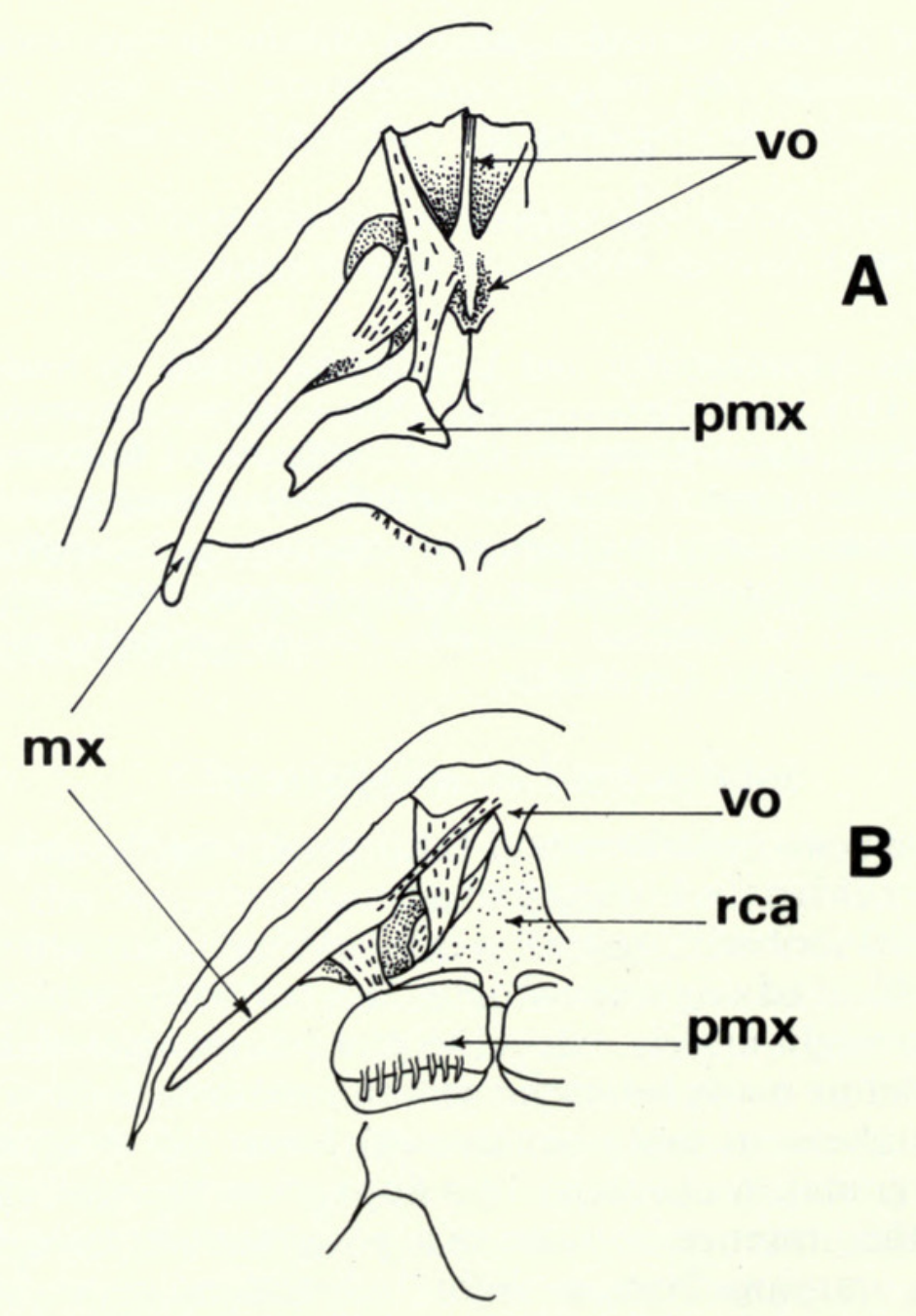

Fig. 21 Ligamentous connections of the upper jaws in A, Loricaria labialis (BMNH 1934.8.20: 368-388) and B, L. jubata (BMNH 1914.5.18: 68-72). Ventral views, both drawn to same scale. $\mathrm{mx}=$ maxilla; $\mathrm{pmx}=$ premaxilla; $\mathrm{rca}=$ rostral cartilage; vo $=$ vomer. 
The length of the lateral ethmoid and morphology of the palatine in Loricaria species are perhaps correlated. For example, in L. cataphracta, the lateral ethmoid is long and shelf-like, the palatine narrow and lamellate with a long posterior process whereas in 'Rineloricaria' teffeana the lateral ethmoid is short and broad and the palatine is also short and broadly convex, lacking a posterior process.

Isbrücker (1981) in discussing the Loricariini notes that there are '... several different types of secondary sexual dimorphism...' within the group. If this is so, then here is a further indication of the group's paraphyly.

\section{Discussion}

\section{The interrelationships of the Loricariidae}

In the latest classification of the order Siluroidei, Chardon (1968) includes the Loricariidae, Astroblepidae and Callichthyidae in the superfamily Loricarioidae within the suborder Loricarioidei. Chardon recognises two other superfamilies as constituting the suborder, the Aspredinoidae and the Trichomycteroidae.

It is doubtful that the aspredinids are closely related to the loricariids and trichomycterids. Chardon used an assortment of apo- and plesiomorph characters involving the swimbladder and Weberian apparatus to unite his groups. There are marked differences in the structure of the swimbladder-Weberian system between the Aspredinidae and the Loricariidae as follows:

$\begin{array}{lll} & \text { Aspredinidae } & \text { Loricariidae } \\ \text { Swimbladder } & \text { Not encapsuled } & \text { encapsuled } \\ \text { Anterior centra } & \text { Elongate } & \text { short } \\ \text { 4th parapophysis } & \text { Short } & \begin{array}{l}\text { contributes to swimbladder } \\ \text { capsule }\end{array}\end{array}$

On the other hand, there are several synapomorphies of the swimbladder-Weberian system and caudal fin skeleton that link the Loricariidae with the Astroblepidae and Callichthyidae (see Alexander, 1964, 1965; and Lundberg \& Baskin, 1969; also below).

As noted above p. 323 the astroblepines have been variously treated as a subfamily of the Loricariidae (Regan, 1911; Gosline, 1947) and as a distinct family (Eigenmann, 1910). There is no doubt that on the basis of synapomorphies presented here the astroblepines must be treated as the sister group to the Loricariidae. Following Chardon's (1968) scheme of classification both families would form the super-family Loricarioidae - this is not, however, in accordance with the cladistic scheme presented in Fig. 22.

Bailey \& Baskin (1976) described a new taxon which they regarded, provisionally as a sub'family of the Loricariidae, the Scoloplacinae. The authors pointed out that its inclusion in the family would necessitate a 'significant expansion' of the Loricariidae. Baskin's (1973, unpublished) cladogram places Scoloplax as the sister group to the Loricariidae + the Astroblepidae, i.e. at family rank. With this I would concur and also follow Isbrücker (1980) in recognising the Scoloplacidae.

The pattern of phylogenetic relationships between the Loricariidae + Astroblepidae and the Nematogenyidae, Trichomycteridae, Callichthyidae and Scoloplacidae has still to be resolved. Baskin (1973, unpublished thesis) has produced a phylogenetic scheme which is essentially like that presented here (Fig. 22). There are, however, several conflicting presumed synapomorphies not taken into account by Baskin. For example the Nematogenyidae shares only with the Trichomycteridae a derived configuration of the opercular musculature (p. 329), but shares only with the Diplomystidae a similarly papillate branchiostegal membrane and buccal roof tissue. Again, the Callichthyidae shares what appear to be derived features of swimbladder encapsulation with the Astroblepidae, Loricariidae and Scoloplacidae, but a premaxillary-ethmoid hinge joint only with the two former families. Lateral ethmoid encapsulation of the nasal organ occurs only in the Loricariidae and Callichthyidae. 


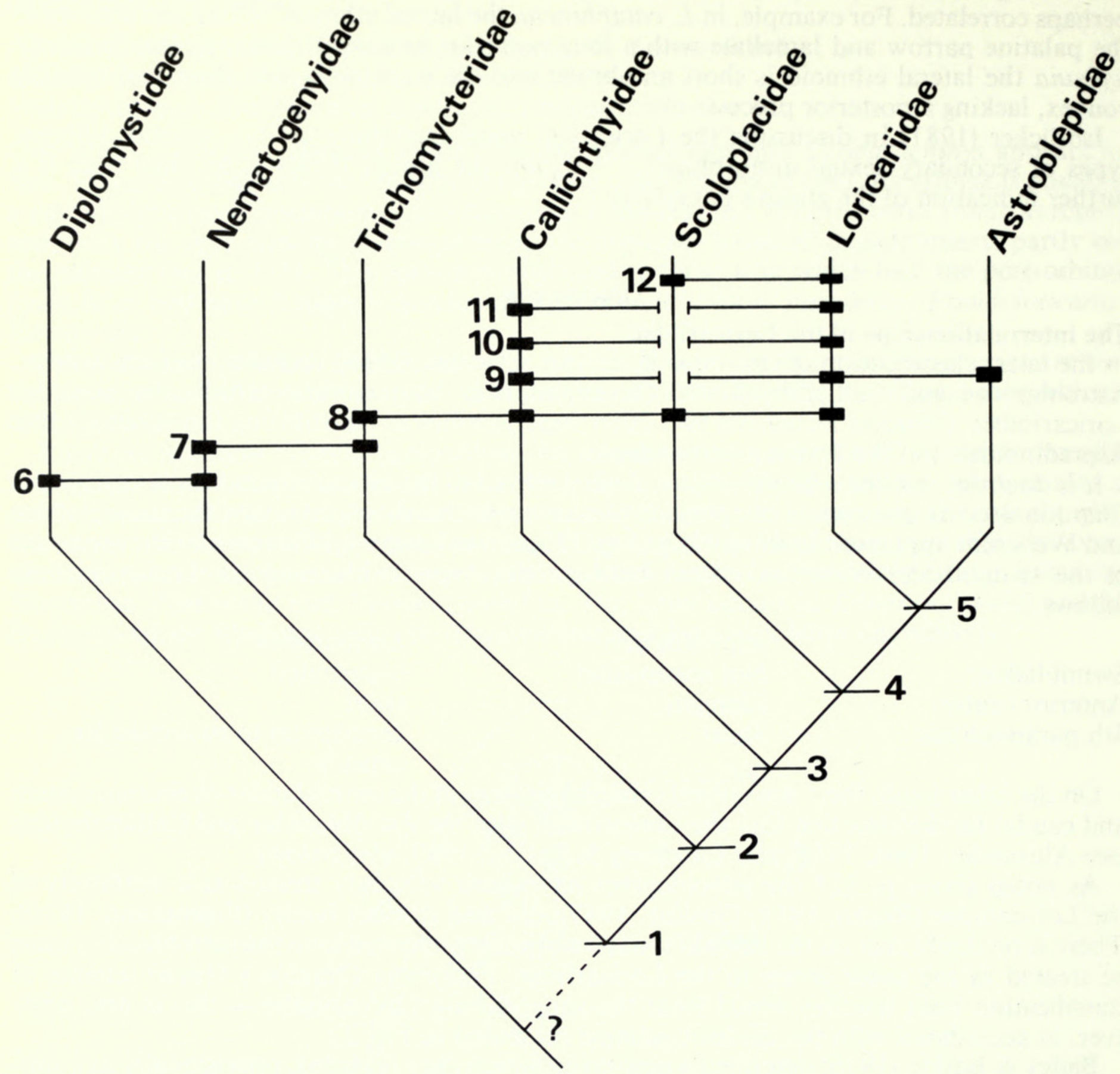

Fig. 22 Hypothesised relationships of the Loricariidae and Astroblepidae. Node $1=$ swimbladder encapsuled, divided into separate vesicles; some part of the cranium contributing to encapsulation; odontodes on fin rays and/or body. Node $2=$ Claustrum and intercalarium lacking from the Weberian vertebral series. Node $3=$ Posttemporal contributing to distal portion of the swimbladder capsule; derived hypural fusion pattern; low number of principal caudal fin rays. Node $4=$ connecting bone between the 1 st rib and the 2 nd pterygiophore. Node $5=$ muscle characters listed in this paper, associated with reverted lip; lateropterygium (see p. 336; 6 fused anterior centra. Line $6=$ papillate branchiostegal membrane and buccal roof tissue. Line $7=$ lateral insertion of the dilatator operculi muscle. Line $8=$ odontodes on opercular bones. Line $9=$ Ethmoid-premaxillary hinge joint. Line $10=$ nasal organ encapsuled in lateral ethmoid. Line $11=$ rows of lateral plates partly or entirely encasing body. Line $12=$ rostal epidermal ossifications bearing odontodes.

Characters 6-12 are incongruent with $1-5$ and so indicate either independent derivation $(9,10$ in Callichthyidae) or secondary loss $(8,11,12$ in Astroblepidae).

The characters listed above are compiled from Gosline (1947), Lundberg \& Baskin (1969), Bailey \& Baskin (1976), Baskin (unpublished thesis, 1973) and personal observation. 
The absence in the Astroblepidae of certain characters linking the Loricariidae, Scoloplacidae, Callichthyidae and Trichomycteridae (i.e. opercular odontodes, body plates) is most parsimoniously explained by secondary loss (see opinions of Bhatti, 1938 and Gosline, 1947 concerning loss of armour in Astroblepus).

As yet, comparative anatomical studies on the various genera presently included in the Callichthyidae are lacking. Such data as are available are summarized in the cladistic scheme presented here (Fig. 22).

\section{Functional considerations}

Several pointers have emerged in the course of this study as to the functional significance of certain myological features. In particular, the medially divided protractor hyoideus signifies independent mobility of the separate halves of the lower jaw. Aquarium observations on a variety of loricariid taxa have confirmed this (pers. obs.). The intermandibularis is only weakly attached to the two halves of the mandible and the bulk of the muscle runs through the lip tissue. It would appear that in loricariids the principal function of the muscle is to activate the lip as a sucker. Alexander (1965) has given an account of lip movement associated with respiration.

The diversity of jaw morphology ranges from long, broad upper and lower jaws (Chaetostoma) to the short, deep inwardly curved lower jaw and coalesced, almost circular, upper jaw of Pseudacanthicus. In both morphotypes the jaws appear highly mobile, but the angles of their respective muscle insertions indicate quite different manipulative abilities.

In astroblepids and loricariids, the upper jaw is free from the restraint imposed by the ankylosed mesethmoid, common to the majority of siluroids. Only in callichthyids has the upper jaw a similar, ligamentous, attachment to the mesethmoid, although here its vertical rotation appears limited through firm attachment to the palatines.

The palatine appears to play a somewhat different functional role in loricariids as compared with other siluroids. Its lack of firm attachment to the ethmoid seems to impart a greater degree of mobility to the bone, and the postero-ventral attachment of part of the extensor tentaculi muscle provides a degree of downward movement lacking in other siluroids. This is particularly marked in the Pseudohemiodon group where the extensor tentaculi has shifted its position to the centre of the centre of the palatine and there is a tendinous palatine-maxillary-premaxillary linkage (see Fig. 5B).

An inferior, sucker-like mouth comparable with that of loricariids occurs elsewhere amongst siluroids in the African genus Euchilichthys and the Asian Glyptothorax and Glyptosternon. In these taxa the muscular insertions to the upper jaw differ from those in loricariids in that the retractor tentaculi inserts for the most part on the premaxilla with a tendinous outer portion running to the maxilla. The palatine is short and is actuated by an extensor tentaculi passing into its medial face. The premaxilla is overlapped by an anterior extension of the mesethmoid and appears to have less mobility than in loricariids.

As noted above, p. 342, loricariids and their relatives have a head and body covering of odontodes and in some taxa these have become elongate and collected in certain areas to form clumps of spines. The spines are of two kinds, those that are embedded in the cheek tissue to which the pediments are attached by ligament (see Bhatti, 1938) and those that are attached to the interoperculum, embedded in small plates. Both types of spine can be shed; according to Moodie \& Power (1982), in Loricaria uracantha, cheek spines develop over a 64 day period and are lost within 148 days. Scars on the interoperculum of male Chaetostoma specimens indicate that the spines have been shed (pers. obs.). Allison, (1980; pers. comm.) reports aquarium observations on the use of interopercular spines in Ancistrus $\mathrm{sp}$. When two males sight one another their initial reaction is to open the interopercular flap and evert the spines rapidly on both sides simultaneously. If one or other fish remains undeterred a 'combat' situation develops with the individuals aligning themselves side by side, everting their opposing spines (those on the blind side remaining withdrawn) and engaging them by sideways movements of the head. These movements are made by strong lateral 
curvatures of the caudal peduncle and tail. These observations suggest that at least in Ancistrus the interopercular spine function is one of display. It is noted that the spines are not as well-developed in females of Ancistrus who nevertheless do display their spines by lateral movements when approached by conspecifics whilst feeding (Allison, pers. comm.).

The fixed cheek spines of Hemipsilichthys and various Loricaria species is also a sexually dimorphic character. In males the cheeks are fringed with long, closely packed spines, whilst those of the females bear small, widely spaced spines. Moodie \& Power (1982) report on the use of pectoral fin and cheek spines in Loricaria uracantha where the male has the ability to rotate forward its pectoral spines so that they lie adjacent to the cheek spines and so probably act as clasping organs during spawning.

According to Eigenmann (1918) trichomycterids use their opercular spines as holdfasts to the substrate. The same function would seem to operate in parasitic trichomycterids, the only difference being the nature of the substrate. Such may be the plesiomorph function of the interopercular spines in loricariids. Aquarium observations suggest that some loricariids use their spines to secure a position in the substrate (Allison, pers. comm.; pers. obs.).

The dilatator operculi muscle is well-developed only in those taxa with a pseudointeropercular spine erecting mechanism, Ancistrus, Pseudacanthicus etc., and its role in activating the operculum in respiratory movements seems restricted. Respiratory activity probably falls largely on the adductor hyohyoidei which extend well up the medial face of the operculum. Often the last branchiostegal ray is attached to the opercular face by the musculature or at least an intervening tissue fascia. The tight seal of the operculum to the cleithrum also suggests its rather passive role in respiration.

\section{Acknowledgements}

My sincere thanks are due to Drs Jon Baskin, Isaac Isbrücker and Mary Power for most informative discussions on loricariid fishes, and to Dr Reeve Bailey (University of Michigan, Museum of Zoology) for the loan of Scoloplax specimens.

Dr Humphry Greenwood's critical reading and discussion of the manuscript has made for a great deal of improvement, and to him I am most grateful.

Special thanks go to David Allison of the Catfish Association of Great Britain for providing me with so much information on the behaviour of loricariids.

\section{References}

Alexander, R. McN. 1964. The structure of the Weberian apparatus in the Siluri. Proc. Zool. Soc. Lond., 142 (3): 419-440.

- 1965. Structure and function of the catfish. J. Zool. Lond., 148: 88-152.

Allison, D. 1980. Family Loricariidae, continued. Catfish Assn. Great Britain Magazine 25: 16-17.

Arratia, F., Chang, G., Menu-Marque, S. \& Rojas, G. M. 1978. About Bullockia gen. nov., Trichomycterus mendozensis n.sp. and revision of the family Trichomycteridae (Pisces, Siluriformes). Stud. Neotrop. Fauna \& Environ., 13: 157-194.

Angelscu, V. \& Gneri, F. S. 1949 Adaptaciones del aparato digestivo al regimen alimenticio en algunos peces del rio Uruguay y del Rio de la Plata. I. Revta. Inst. nac. Invest. Cienc. nat. Mus. argent. Cienc. nat. Bernardino Rivadavia. Ciencias Zool. 1 (6): 161-272.

Bailey, R. M. \& Baskin, J. N. 1976. Scoloplax dicra, a new armoured catfish from the Bolivian Amazon. Occ. Pap. Mus. Zool. Univ. Mich. 674: 1-14.

Baskin, J. N. 1973. Structure and relationships of the Trichomycteridae. Unpublished thesis.

Bhatti, H. K. 1938. The integument and dermal skeleton of Siluroidea. Trans. Zool. Soc. Lond., 24, (1): $1-102$.

Chardon, M. 1968. Anatomie comparée de l'appareil de Weber et des structures connexes chez les Siluriformes. Annls Mus. Afr. cent. Ser. $8^{\circ}$ Sci. Zool., 169: 1-277. 
Eigenmann, C. H. 1910. Catalogue of the fresh-water fishes of tropical and south temperate America. Rep. Princeton Univ. Exped. Patagonia 3(4) (Zool.): 375-511.

— 1918. The Pygidiidae, a family of South American catfishes. Mem. Carnegie Mus. 7 (5): 259-398. 1928. The fresh-water fishes of Chile. Mem. Nat. Acad. Sci. 22: 1-63.

Fink, S. V. \& Fink, W. 1981. Interrelationships of the ostariophysan fishes (Teleostei). Zool. J. Linn. Soc. 72 (4): 297-353.

Fowler, H. W. 1958. Some new taxonomic names of fishlike vertebrates. Notul. nat., 310: 1-16.

Gosline, W. A. 1947. Contributions to the classification of the loricariid catfishes. Arq. Mus. Nac. Rio de Janeiro, 41: 79-134.

Gregory, W. K. 1933. Fish skulls. A study of the evolution of natural mechanisms. Trans. Amer. philos. Soc., 23 (2): 75-481.

Holmes, E. B. 1980. Reconsideration of some systematic concepts and terms. Evolutionary Theory, 5: $35-87$.

Howes, G. J. 1981. Anatomy and phylogeny of the Chinese major carps Ctenopharyngodon Steind., 1866 and Hypophthalmichthys Blkr, 1860. Bull. Br. Mus. nat. Hist. (Zool.) 41 (1): 1-52.

- 1983. Problems in catfish anatomy and phylogeny as exemplified by the Neotropical Hypophthalmidae (Teleostei: Siluroidei). Bull. Br. Mus. nat. Hist. (Zool.), 45(1): 1-39.

Isbrücker, I. J. H. 1980. Classification and catalogue of the mailed Loricariidae (Pisces, Siluriformes). Versl. Techn. Geg., Inst. Taxon. Zool. (Zool. Mus.) Univ. Amsterdam, 22: 1-181.

- 1981. Revision of Loricaria Linnaeus, 1758 (Pisces, Siluriformes, Loricariidae). Beaufortia, 30 (3): 51-96.

Leege, C. O. 1922. Der Rumpfpanzer der Panzerwelse und seine Skelettbeziehungen (Plecostomus angipinnatus n. sp., Callichthys callichthys L. und Corydoras paleatus Jen.). Jena Z. Naturw., 58 (NS) 51 (2): 145-270.

Lundberg, J. G. \& Baskin, J. N. 1969. The caudal skeleton of the catfishes, order Siluriformes. $A m$. Mus. Novitates, 2398: 1-49.

Matthes, H. 1963. A comparative study of the feeding mechanism of some African Cyprinidae (Pisces, Cypriniformes). Bijdr. Dierk., 33: 3-35.

Mithel, M. 1964. The cranial nerves of the sisorid catfish Bagarius bagarius. Copeia 1964 (4): $673-678$.

Moodie, G. E. E. \& Power, M. 1982. The reproductive biology of an armoured catfish, Loricaria uracantha, from Central America. Env. Biol. Fish., 7 (2): 143-148.

Ørvig, T. 1977. A survey of odontodes ('dermal teeth') from developmental, structural, functional, and phyletic points of view. In: Problems of vertebrate evolution ed. S. Mahala Andrews, R. S. Miles \& A. D. Walker. Linn. Soc. Symp. Ser., 4: 53-75.

Peyer, B. 1922. Über die Flossenstacheln der Welse und Panzerwelse, sowie des Karpfens. Morph. Jahjr. 51: 493-554.

Regan, C. T. 1904. A monograph of the fishes of the family Loricariidae. Trans. zool. Soc. Lond., 17 (3): 191-350.

1911. The classification of the teleostean fishes of the order of Ostariophysi. 2. Siluroidea. Ann. Mag. nat. Hist., 8 (8): 553-577.

Starks, E. C. 1926. Bones of the ethmoid region of the fish skull. Stanford Univ. Publ. Biol. Sci., 46: 137-338.

Vari, R. P. 1979. Anatomy, relationships and classification of the families Citharinidae and Distichodontidae (Pisces, Characoidea). Bull. Br. Mus. nat. Hist. (Zool.), 36 (5): 261-344.

Vaz-Ferreira, R. \& Señorans, J. S. 1971. Oviposicion e incubacion de Plecostomus alatus Castelnau, en cuevas. Bol. Soc. Zool. Uruguay, 1: 12-17.

Vetter, B. 1878, Untersuchungen zur vergleichende Anatomie der Kiemen- und Kiefermuskulatur der Fische II. Jena Z. Naturw., 12 (3): 431-550.

Winterbottom, R. 1974. A descriptive synonymy of the striated muscles of the teleostei. Proc. Acad. nat. Sci. Philad., 125 (12): 225-317. 


\section{$2 \mathrm{BHL}$ Biodiversity Heritage Library}

Howes, G J. 1983. "The cranial muscles of the loricarioid catfishes, their homologies and value as taxonomic characters (Teleostei: Siluroidei)." Bulletin of the British Museum (Natural History) Zoology 45, 309-345. https://doi.org/10.5962/bhl.part.28003.

View This Item Online: https://www.biodiversitylibrary.org/item/19634

DOI: https://doi.org/10.5962/bhl.part.28003

Permalink: https://www.biodiversitylibrary.org/partpdf/28003

\section{Holding Institution}

Natural History Museum Library, London

\section{Sponsored by}

Natural History Museum Library, London

\section{Copyright \& Reuse}

Copyright Status: In copyright. Digitized with the permission of the rights holder.

Rights Holder: The Trustees of the Natural History Museum, London

License: http://creativecommons.org/licenses/by-nc-sa/4.0/

Rights: http://biodiversitylibrary.org/permissions

This document was created from content at the Biodiversity Heritage Library, the world's largest open access digital library for biodiversity literature and archives. Visit BHL at https://www.biodiversitylibrary.org. 